\title{
Fluorine labeling of ortho-phenylenes to facilitate
}

\section{conformational analysis}

Viraj C. Kirinda ${ }^{\mathrm{a}}$, Gopi Nath Vemuri ${ }^{\mathrm{a}}$, Nicholas G. Kress ${ }^{\mathrm{a}}$, Kaitlyn M.

Flynn $^{\mathrm{a}}$, Nuwanthika Dilrukshi Kumarage ${ }^{\mathrm{a}}$, Briana R. Schrage ${ }^{\mathrm{b}}$, David L.

Tierney $^{\mathrm{a}}$, Christopher J. Ziegler ${ }^{\mathrm{b}}$, and C. Scott Hartley*a

\author{
a Department of Chemistry \& Biochemistry, Miami University, Oxford, Ohio \\ 45056, United States \\ ${ }^{\mathrm{b}}$ Department of Chemistry, University of Akron, Akron, Ohio 44325, United \\ States
}

\begin{abstract}
${ }^{1} \mathrm{H}$ NMR spectroscopy is a powerful tool for the conformational analysis of orthophenylene foldamers in solution. However, as o-phenylenes are integrated into evermore-complex systems, we are reaching the limits of what can be analyzed by ${ }^{1} \mathrm{H}$ and ${ }^{13} \mathrm{C}$-based NMR techniques. Here, we explore fluorine labeling of $o$-phenylene oligomers for analysis by ${ }^{19} \mathrm{~F}$ NMR spectroscopy. Two series of fluorinated oligomers have been synthesized. Optimization of monomers for Suzuki coupling enables an efficient stepwise oligomer synthesis. The oligomers all adopt well-folded geometries in solution, as determined by ${ }^{1} \mathrm{H}$ NMR spectroscopy and X-ray crystallography. ${ }^{19} \mathrm{~F}$ NMR experiments complement these methods well. The resolved singlets of one-dimensional ${ }^{19} \mathrm{~F}\left\{{ }^{1} \mathrm{H}\right\}$ spectra are very useful for determining relative conformer populations. The
\end{abstract}


additional information from two-dimensional ${ }^{19} \mathrm{~F}$ NMR spectra is also clearly valuable when making ${ }^{1} \mathrm{H}$ assignments. Comparison of ${ }^{19} \mathrm{~F}$ isotropic shielding predictions to experimental chemical shifts is not, however, currently sufficient by itself to establish o-phenylene geometries.

\section{Introduction}

Molecular folding generates the nanoscale structural complexity needed in biochemical systems. Interest in mimicking the capabilities of these systems, and the promise of novel ones, has inspired the design and synthesis of foldamers, oligomers that fold into well-defined conformations $^{1,2}$ as a result of non-covalent interactions (e.g., hydrogen bonding, arene stacking, etc.). ${ }^{3}$ Foldamers have been reported that exhibit unusual reactivities, ${ }^{4-6}$ motion, ${ }^{7,8}$ catalysis, ${ }^{9,10}$ chiral amplification, ${ }^{11,12}$ and molecular recognition. ${ }^{13-16}$

The o-phenylenes are structurally simple foldamers with rich conformational behavior. While they were first reported more than 60 years ago, ${ }^{17}$ Simpkins was the first to prepare $o_{-}$ phenylenes using modern synthetic techniques, also demonstrating that they can adopt helical geometries in the solid-state. ${ }^{18}$ Later reports from $\mathrm{us}^{19}$ and Fukushima and Aida ${ }^{20}$ showed that well-folded conformations also predominate in solution. The conformational behavior of $o$-phenylenes is now fairly well understood. ${ }^{21,22}$ Generally, the most-stable conformer has a compact helical structure, shown in Figure 1 for hexa(o-phenylene), that maximizes intramolecular arene-arene stacking interactions. Since these interactions are relatively weak (approximately $0.5 \mathrm{kcal} / \mathrm{mol}$ for the parent series in chloroform ${ }^{23}$ ), o-phenylene folding tends to be dynamic and misfolded species are usually observable.

${ }^{1} \mathrm{H}$ NMR spectroscopy provides deep insight into the folding of $o$-phenylenes. ${ }^{22}$ Their conformational changes are typically slow on the NMR time scale (but fast on the lab time scale). The movement of key protons in and out of nearby aromatic shielding zones causes significant changes in ${ }^{1} \mathrm{H}$ chemical shifts (on the order of $1 \mathrm{ppm}$ ) that are predictable using computational methods. Thus, the NMR spectra of a typical o-phenylene can be deconvoluted 

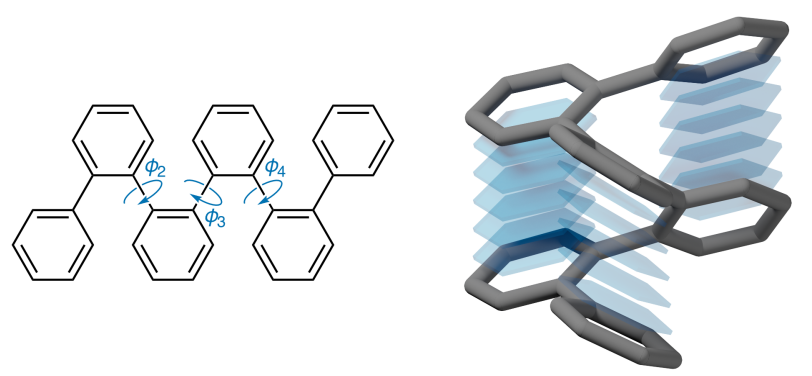

Figure 1: Folding of hexa(o-phenylene) is dictated by the three internal biaryl dihedral angles (left). Folding into a compact helical structure is governed by arene-arene stacking interactions between every third repeat unit (right).

to determine chemical shift assignments for each observable conformer, typically with the help of EXSY spectra. ${ }^{24} \mathrm{Ab}$ initio chemical shift predictions on libraries of possible conformers can then be used to match these chemical shifts to specific geometries.

We have used this strategy to analyze $o$-phenylene folding within structurally complex systems. For example, macrocycles with multiple o-phenylene moieties, simple examples of higher-order structure, exhibit predictable misfolding because of structural restrictions. ${ }^{25-27}$ Further, o-phenylenes have been functionalized with chiral groups to promote a preferred handedness to their folding, with a nuanced relationship between group orientation and the sense of chiral induction. ${ }^{28}$ These systems give complex ${ }^{1} \mathrm{H}$ NMR spectra, with contributions from multiple inequivalent $o$-phenylene species, that ultimately yielded detailed information about conformational distributions.

We are, however, reaching the limits of what can be accomplished in the analysis of $o$-phenylene foldamers by ${ }^{1} \mathrm{H}$ - and ${ }^{13} \mathrm{C}$-based NMR spectroscopy alone. New strategies are required if they are to be used in ever-more complex systems. Of course, biochemistry, the inspiration for the field, has long struggled with this same problem. One solution is the use of ${ }^{19} \mathrm{~F}$ labeling and thus analysis by ${ }^{19} \mathrm{~F}$ NMR spectroscopy. ${ }^{29-31}$ Indeed, examples of fluorinated peptidic foldamers have been reported, ${ }^{32-35}$ as have a handful of examples of fluorinated aromatic foldamers. ${ }^{36-39}$ In some cases, ${ }^{19} \mathrm{~F}$ NMR spectroscopy provides new insight into their behavior. $^{33,35,37-39}$

We reasoned that ${ }^{19} \mathrm{~F}$ NMR could be particularly useful as a spectroscopic label for 
o-phenylenes. Most importantly, ${ }^{19} \mathrm{~F}$ has chemical shift sensitivity towards aromatic shielding zones. ${ }^{36}$ Further, fluoro groups are convenient substituents: they are small, they promote $o$-phenylene folding by strengthening arene-arene stacking (because they are electronwithdrawing), ${ }^{40}$ and, as single atoms, they are straightforward to include in computational models (unlike commonly used acetoxy groups, which can adopt many possible geometries).

In this work, we investigate representative fluorinated $o$-phenylenes to assess their synthetic accessibilities and the benefits of ${ }^{19} \mathrm{~F}$ NMR methods in conformational analysis. We report synthetic methods suitable for the construction of long fluorinated $o$-phenylene oligomers. Conformational populations have been established using traditional ${ }^{1} \mathrm{H}$ NMR methods and X-ray crystallography, which inform the analysis of ${ }^{19} \mathrm{~F}$ NMR spectra. The advantages and limitations of ${ }^{19} \mathrm{~F}$ NMR spectroscopy for conformational analysis of $o$-phenylenes are discussed.

\section{Results and Discussion}

\section{Design and Synthesis}

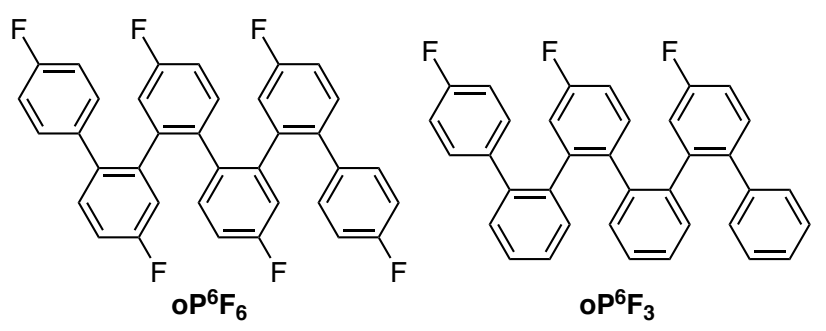

Chart 1: Fluorinated $o$-phenylene hexamers.

We designed compounds $\mathbf{o P}^{\mathbf{6}} \mathbf{F}_{\mathbf{6}}$ and $\mathbf{o P}^{\mathbf{6}} \mathbf{F}_{\mathbf{3}}$ in Chart 1 as our first steps in assessing the usefulness of fluorine labeling in $o$-phenylenes. These oligomers are short enough that independent determination of their folding behavior using ${ }^{1} \mathrm{H}$ NMR spectroscopy is straightforward. The syntheses, shown in Scheme 1, were based on Manabe's strategy for polyphenylene synthesis using hydroxy-functionalized boronic acids, ${ }^{41}$ since similar methods have been 
successfully employed previously. ${ }^{19}$ The syntheses rely on two key fluorinated boroxarenes, ${ }^{42}$ B1 and B2.

While both target compounds were successfully obtained in sufficient quantities for analysis, the yields were too low for this strategy to be generalized. Fluorinated arenes are less reactive than their non-fluorinated analogues under standard Suzuki coupling conditions because of a difficult transmetalation step. ${ }^{43}$ Since coupling preferably happens when the boronic acid group is meta to the fluoro substituent, ${ }^{44}$ we attempted to use fluoroboroxarene monomer B3 as shown in Scheme 2. However, after modest success in the first coupling, further extension of the o-phenylene was unsuccessful.

(a)
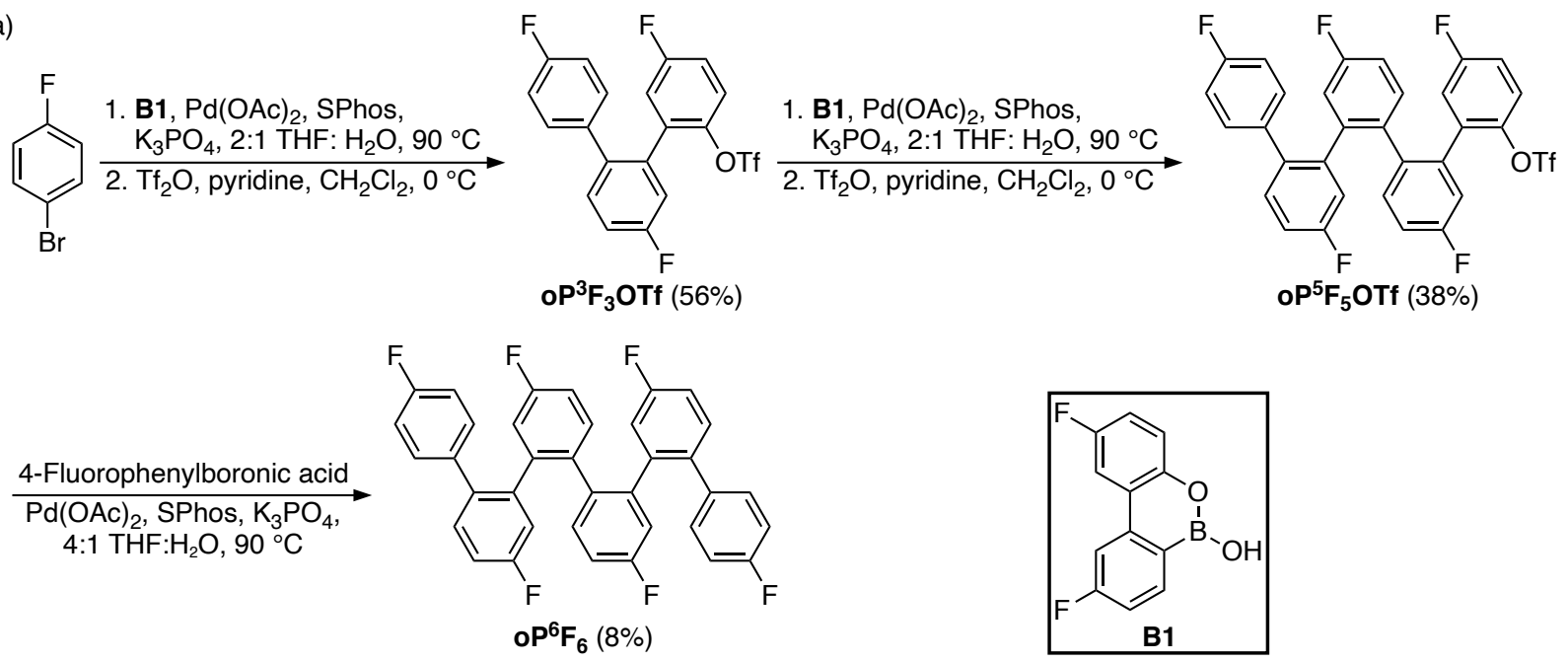

(b)
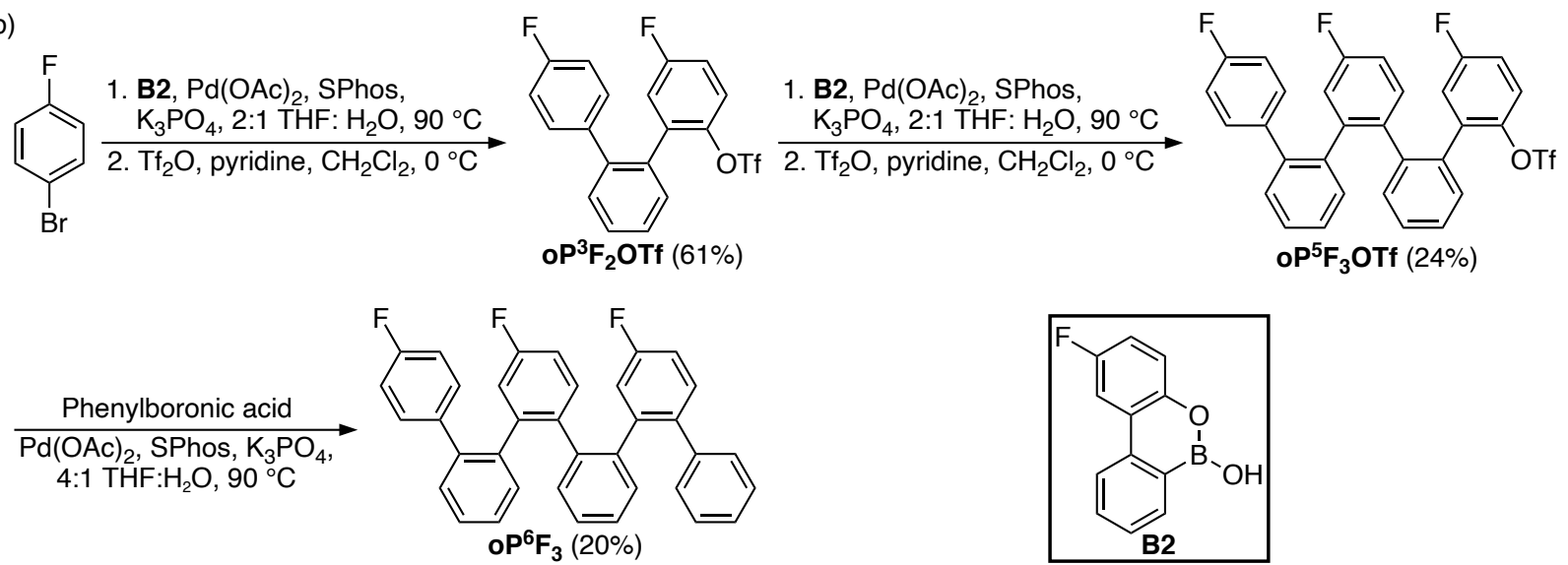

Scheme 1: Synthesis of (a) $\mathbf{o} \mathbf{P}^{\mathbf{6}} \mathbf{F}_{\mathbf{6}}$ and (b) $\mathbf{o} \mathbf{P}^{\mathbf{6}} \mathbf{F}_{\mathbf{3}}$.

Additional model experiments (shown in the Supporting Information) indicated that 

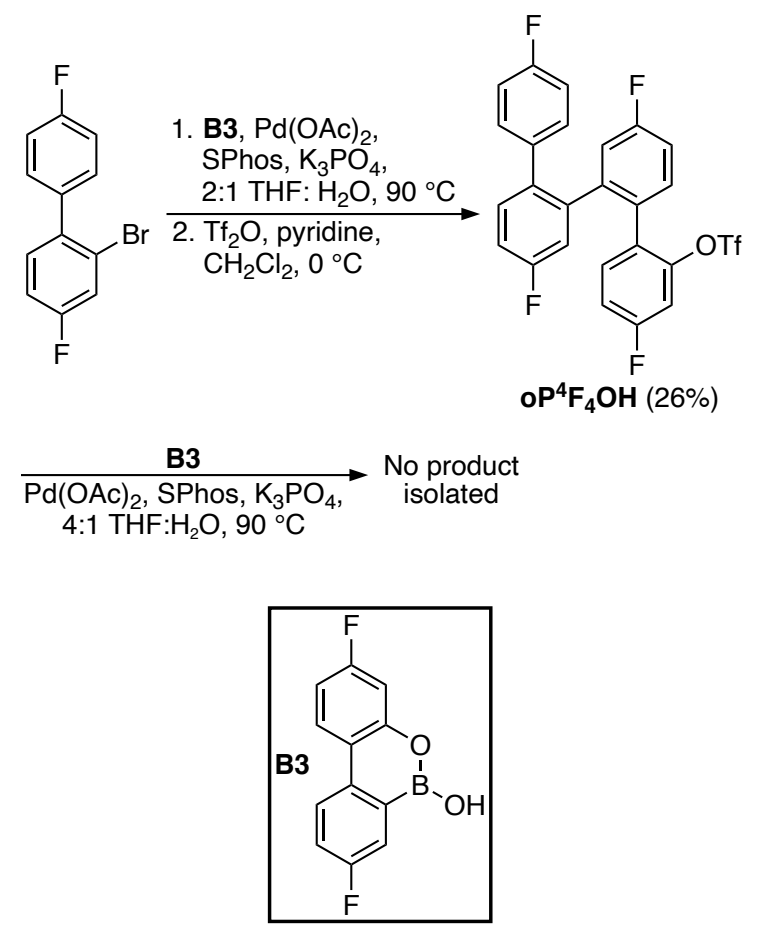

Scheme 2: Reactions attempted with fluoroboroxarene B3.

the problem was fluoro substitution of the ring bearing the (pseudo)halogen. Since, in general, there is no need to fluorine-label every possible repeat unit of the oligomer, we designed fluoroboroxarene B4 (Scheme 3), which is fluorinated only at the boron-bearing ring. This monomer was successfully applied to the synthesis the series of $o$-phenylenes ${ }^{\mathbf{o P}} \mathbf{F O T f}^{4} \mathbf{\text { oP }}{ }^{\mathbf{1 0}} \mathbf{F}_{\mathbf{4}} \mathbf{O T f}$ in reasonable yields, as shown in Scheme 3. Members of this series longer than $\mathbf{o P}^{\mathbf{1 0}} \mathbf{F}_{4} \mathbf{O T f}$ could not be obtained because of poor solubility.

\section{Conformational analysis}

We then analyzed the folding behavior of $\mathbf{o P}^{\mathbf{6}} \mathbf{F}_{\mathbf{6}}$ and $\mathbf{o P}^{\mathbf{6}} \mathbf{F}_{\mathbf{3}}$. We have developed an idealized but useful model for understanding o-phenylene conformational behavior. ${ }^{22}$ Briefly, the backbone conformation of an $o$-phenylene $[n]$-mer is determined by its $n-3$ internal biaryl torsional angles $\phi_{i}$ (shown in Figure 1 for hexa(o-phenylene)). For the well-folded conformer, all of the internal dihedral angles are approximately $-55^{\circ}$ or $+55^{\circ}$, which we label the "A" and " $\mathrm{A}$ " states, respectively, corresponding to left- and right-handed helices. In misfolded 


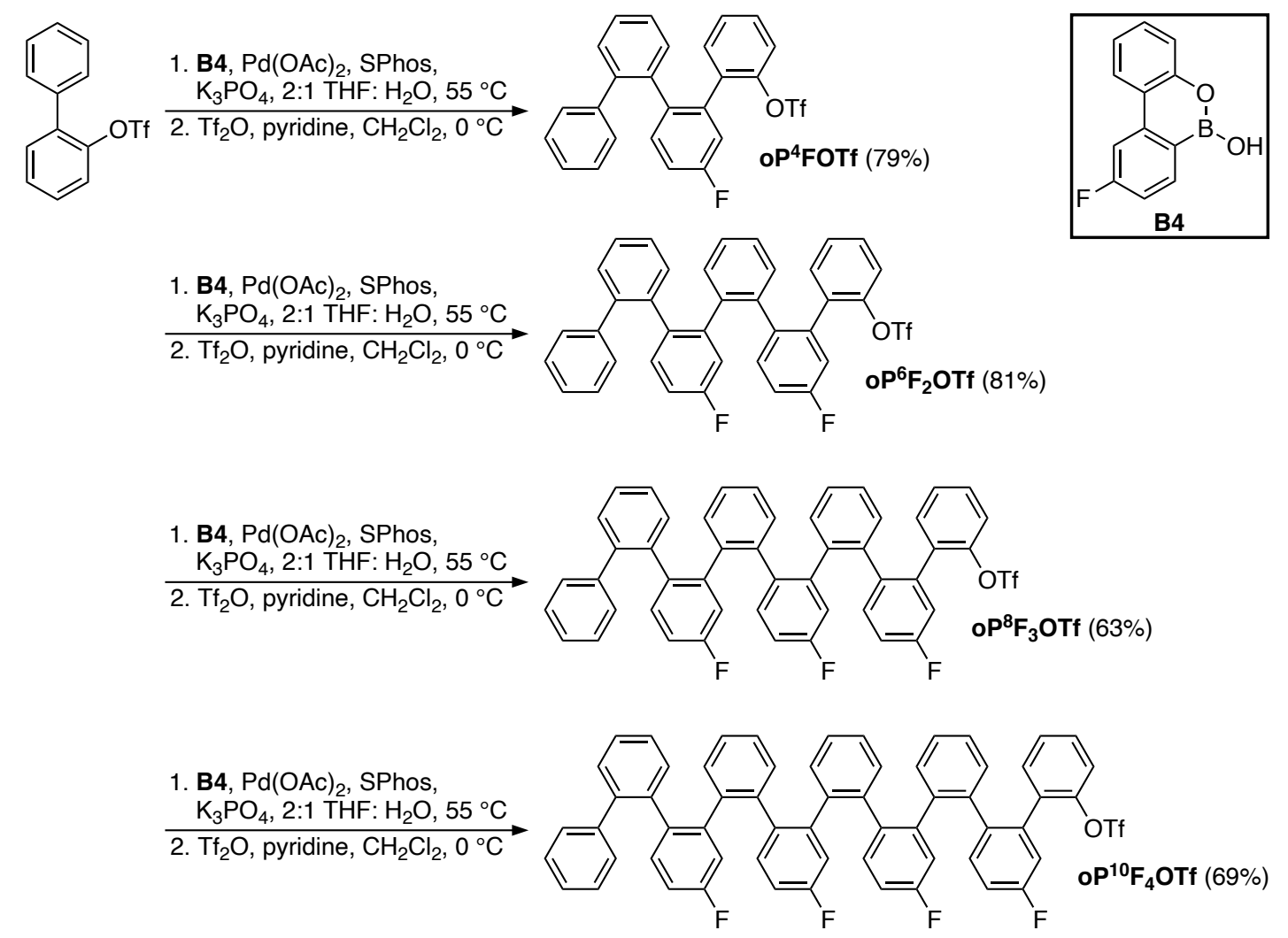

Scheme 3: Synthetic scheme for longer fluorinated o-phenylenes.

geometries, one or more of the $\phi_{i}$ are approximately $+135^{\circ}$ or $-135^{\circ}$, which we label the "B" and " $\mathrm{B}^{\prime \prime}$ " states. Two rules govern this model. First, within a single molecule only A and B, or $\mathrm{A}^{\prime}$ and $\mathrm{B}^{\prime}$, states can coexist (i.e., $\mathrm{A}$ and $\mathrm{A}^{\prime}, \mathrm{A}$ and $\mathrm{B}^{\prime}$, etc., are incompatible). Second, the "ABA" sequence of torsional angles is forbidden because of sterics.

X-ray crystallography provides initial insight into the folding of $\mathbf{o P}^{\mathbf{6}} \mathbf{F}_{\mathbf{3}}$ and $\mathbf{o P}^{\mathbf{6}} \mathbf{F}_{\mathbf{6}}$. Single crystals were grown by the layer diffusion method using dichloromethane and ethanol. The resulting solid-state structures are shown in Figure 2. Both $\mathbf{o P}^{\mathbf{6}} \mathbf{F}_{\mathbf{3}}$ and $\mathbf{o P}^{\mathbf{6}} \mathbf{F}_{\mathbf{6}}$ have
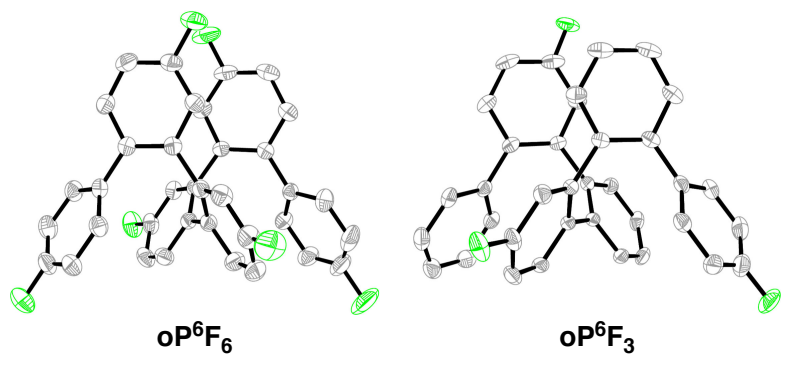

Figure 2: Crystal structures of $\mathbf{o P}^{\mathbf{6}} \mathbf{F}_{\mathbf{6}}$ and $\mathbf{o P}^{\mathbf{6}} \mathbf{F}_{\mathbf{3}}$. 
monoclinic crystal systems but different space groups $\left(C 2 / c\right.$ and $P 2_{1} / n$, respectively). Both the symmetric $\mathbf{o P}^{\mathbf{6}} \mathbf{F}_{\mathbf{6}}$ and asymmetric $\mathbf{o P}^{\mathbf{6}} \mathbf{F}_{\mathbf{3}}$ have screw axes parallel to the $y$-axis and a glide plane perpendicular to the screw axes. Both $\mathbf{o P}^{6} \mathbf{F}_{\mathbf{6}}$ and $\mathbf{o P}^{6} \mathbf{F}_{\mathbf{3}}$ adopt the AAA (and $\left.\mathrm{A}^{\prime} \mathrm{A}^{\prime} \mathrm{A}^{\prime}\right)$ geometries, with internal dihedral angles of $54.0^{\circ} / 58.3^{\circ} / 54.0^{\circ}$ and $57.8^{\circ} / 58.3^{\circ} / 55.7^{\circ}$, respectively. This quasi- $C_{2}$-symmetric, folded helical geometry is typical of hexa(o-phenylenes) in the solid state, ${ }^{18,23,40}$ although different folding states are sometimes observed. ${ }^{19}$

${ }^{1} \mathrm{H}$ NMR spectroscopy was then used to probe solution-phase behavior, including COSY, HSQC, HMBC, and NOESY/EXSY experiments. The spectra were recorded at $0{ }^{\circ} \mathrm{C}$ because the peaks were somewhat sharper than at room temperature, as is typical. ${ }^{45}$ Figure 3a shows 1D spectra for both compounds. The spectrum of the $C_{2}$-symmetric $\mathbf{o P}^{\mathbf{6}} \mathbf{F}_{\mathbf{6}}$ was significantly less complicated than that of the unsymmetric $\mathbf{o P}^{\mathbf{6}} \mathbf{F}_{\mathbf{3}}$. Each spectrum comprises a set of more-intense signals corresponding to the major conformer present in solution, along with smaller signals assigned to minor conformers (as confirmed by EXSY). Proton assignments were straightforward and unambiguous for the major conformers of both $\mathbf{o P}^{\mathbf{6}} \mathbf{F}_{\mathbf{6}}$ and $\mathbf{o P}^{\mathbf{6}} \mathbf{F}_{\mathbf{3}}$.

The better-resolved ${ }^{1} \mathrm{H}$ NMR spectrum of $\mathbf{o P}^{\mathbf{6}} \mathbf{F}_{\mathbf{6}}$ made for relatively easy assignment of the signals corresponding to the minor conformers on the basis of ${ }^{1} \mathrm{H}-{ }^{1} \mathrm{H}$ EXSY cross-peaks (see Supporting Information, Figure S85). Each signal from the major conformer corresponded to two EXSY cross-peaks, indicating that the minor conformer is unsymmetrical. The signals for the minor conformer are quite weak, creating some uncertainty in the final assignments (i.e., missing ${ }^{1} \mathrm{H}-{ }^{13} \mathrm{C}$ HMBC correlations make the precise sequence of assignments along the backbone uncertain). In contrast, because of its inherently lower symmetry, the assignments of the signals corresponding to the minor conformer of $\mathbf{o P}^{6} \mathbf{F}_{\mathbf{3}}$ are unambiguous.

Once the proton chemical shifts were assigned, the geometries corresponding to each conformer were identified using computational isotropic shielding predictions. Previous work has shown that this method gives highly reliable results for acyclic $o$-phenylenes. ${ }^{22}{ }^{1} \mathrm{H}$ isotropic shieldings $(\sigma)$ of $\mathbf{o P}^{\mathbf{6}} \mathbf{F}_{\mathbf{6}}$ and $\mathbf{o} \mathbf{P}^{\mathbf{6}} \mathbf{F}_{\mathbf{3}}$ were calculated at the GIAO/PCM $\left(\mathrm{CHCl}_{3}\right) / \mathrm{WP} 04 / 6$ 31G(d)//B97-D/cc-pVDZ level. ${ }^{46}$ These were then compared with the experimental chemical 
(a) $\mathrm{OP}^{6} \mathrm{~F}_{6}$

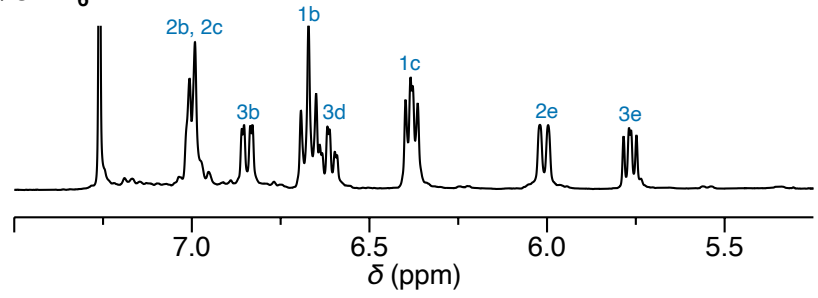

(b) $\mathrm{oP}^{6} \mathrm{~F}_{6}$

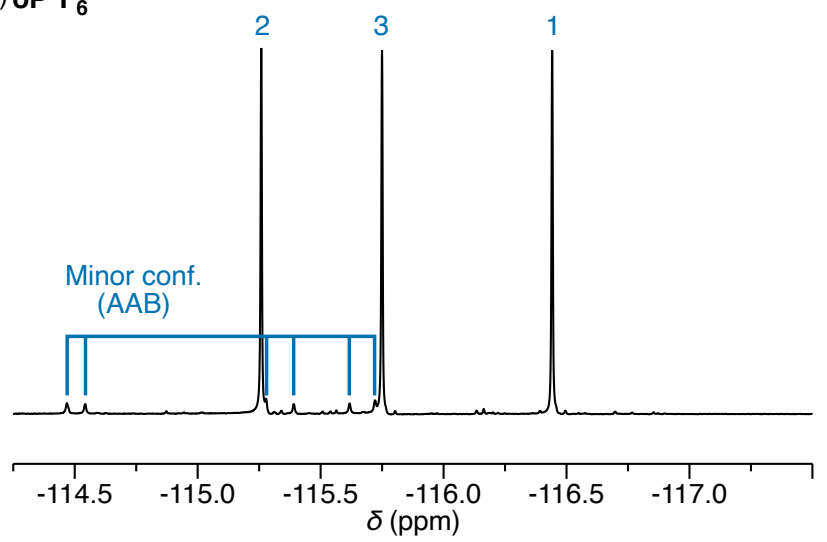

(c)
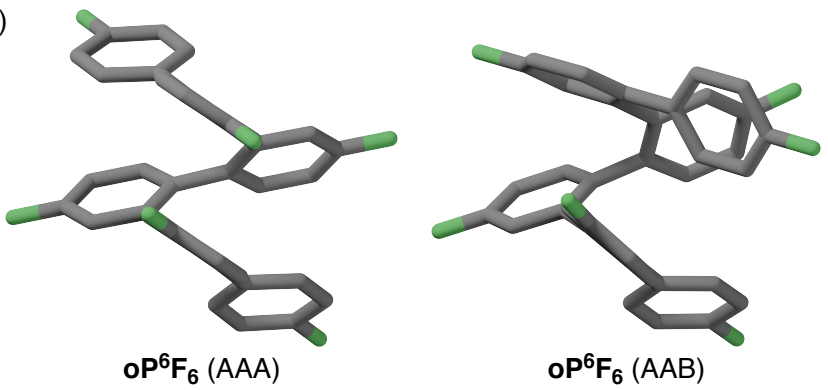

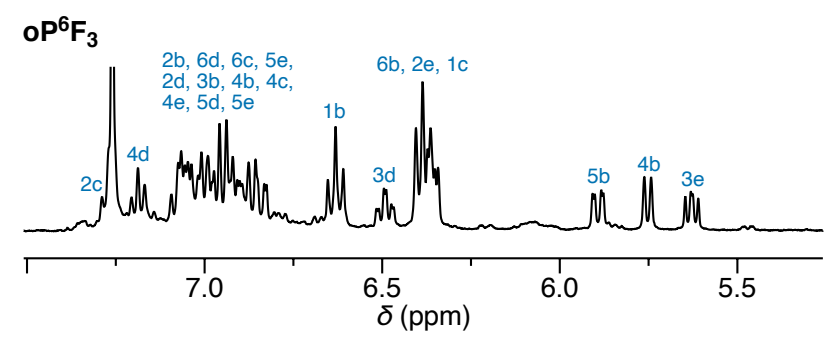

$\mathrm{OP}^{6} \mathrm{~F}_{3}$
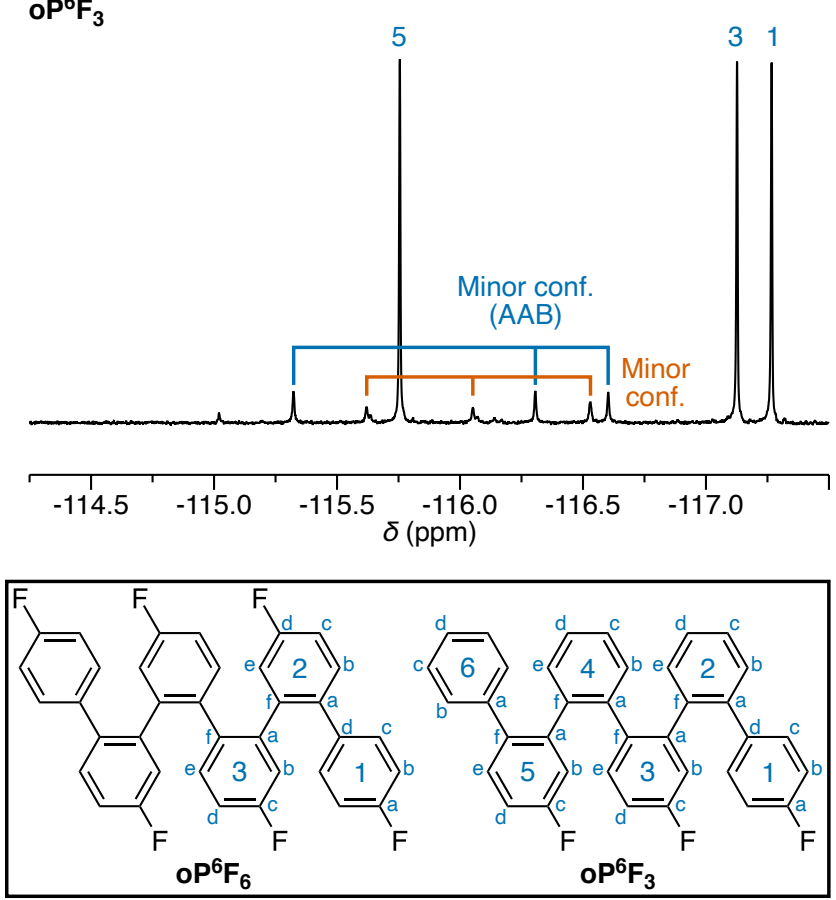

Figure 3: (a) ${ }^{1} \mathrm{H}$ NMR and (b) ${ }^{19} \mathrm{~F}\left\{{ }^{1} \mathrm{H}\right\}$ spectra $\left(0{ }^{\circ} \mathrm{C}\right)$ of $\mathbf{o P}^{\mathbf{6}} \mathbf{F}_{\mathbf{6}}$ (left) and $\mathbf{o P}^{\mathbf{6}} \mathbf{F}_{\mathbf{3}}$ (right). (c) Optimized geometries $\left(\mathrm{PCM}\left(\mathrm{CHCl}_{3}\right) / \mathrm{B} 97-\mathrm{D} / \mathrm{cc}-\mathrm{pVDZ}\right)$ of $\mathbf{o P}^{\mathbf{6}} \mathbf{F}_{\mathbf{6}}$ in the AAA and AAB geometries. 
shifts to predict the geometries for each conformer (see Supporting Information, Figure S7). For both $\mathbf{o P}^{\mathbf{6}} \mathbf{F}_{\mathbf{6}}$ and $\mathbf{o} \mathbf{P}^{\mathbf{6}} \mathbf{F}_{\mathbf{3}}$, the major conformers in solution were determined to be the perfectly folded AAA states, as observed in the solid state. The minor conformers have the AAB geometries, as expected. ${ }^{22}$ Figure $3 \mathrm{c}$ shows optimized geometries for these conformers for $\mathbf{o P}^{\mathbf{6}} \mathbf{F}_{\mathbf{6}}$. In all cases, RMSDs between the experimental and (scaled) calculated chemical shifts are smaller than $0.2 \mathrm{ppm}$, which is typical for this method. The matches are better than the second-best matches at $>99.8 \%$ confidence levels (see Supporting Information).

Conformer populations were calculated from the relative intensities of well-isolated ${ }^{1} \mathrm{H}$ signals. Oligomer $\mathbf{o P}^{\mathbf{6}} \mathbf{F}_{\mathbf{6}}$ has a 92:8 ratio of AAA:AAB, whereas $\mathbf{o P}^{\mathbf{6}} \mathbf{F}_{\mathbf{3}}$ has a 91:9 ratio. It is clear, however, that there are additional conformations present in $\mathbf{o P}^{\mathbf{6}} \mathbf{F}_{\mathbf{3}}$ that cannot be easily quantified using the 1D ${ }^{1} \mathrm{H}$ NMR spectrum because of signal overlap.

The ${ }^{19} \mathrm{~F}\left\{{ }^{1} \mathrm{H}\right\}$ NMR spectra of both hexamers, shown in Figure 3b, are, of course, much simpler than the ${ }^{1} \mathrm{H}$ NMR spectra. Using the ${ }^{1} \mathrm{H}$ assignments, the major signals could be unambiguously identified by the ${ }^{1} \mathrm{H}-{ }^{19} \mathrm{~F}$ hetero-COSY spectra in Figure 4a. ${ }^{47,48}$ Both ${ }^{19} \mathrm{~F}\left\{{ }^{1} \mathrm{H}\right\}$ NMR spectra also show sets of smaller signals, which were confirmed to be from minor conformers by the ${ }^{19} \mathrm{~F}-{ }^{19} \mathrm{~F}$ EXSY spectra in Figure $4 \mathrm{~b} .{ }^{49}$ These signals are easily distinguished from those for the major conformers, showing that ${ }^{19} \mathrm{~F}$ chemical shifts are sensitive to o-phenylene conformation. Importantly, a second significant conformer of $\mathbf{o P}^{\mathbf{6}} \mathbf{F}_{\mathbf{3}}$, presumably BAA, is apparent in the ${ }^{19} \mathrm{~F}$ spectra but had not been initially identified with the ${ }^{1} \mathrm{H}$-based spectra alone.

The minor signals are better resolved in the ${ }^{19} \mathrm{~F}\left\{{ }^{1} \mathrm{H}\right\}$ spectra compared to the ${ }^{1} \mathrm{H}$ NMR spectra. As a consequence, determining the relative conformer populations is much more straightforward. For $\mathbf{o P}^{\mathbf{6}} \mathbf{F}_{\mathbf{6}}$, the ${ }^{19} \mathrm{~F}\left\{{ }^{1} \mathrm{H}\right\}$ NMR spectrum gives $91 \%$ perfectly folded AAA conformer and $9 \%$ AAB, in good agreement with the ${ }^{1} \mathrm{H}$ NMR results. $\mathbf{o P}^{\mathbf{6}} \mathbf{F}_{\mathbf{3}}$ has $80 \%$ AAA conformer, $11 \%$ of AAB conformer, and $9 \%$ of the (likely) BAA conformer, also in good agreement with the ${ }^{1} \mathrm{H}$ NMR results, but with the addition of the third significant folding state. 

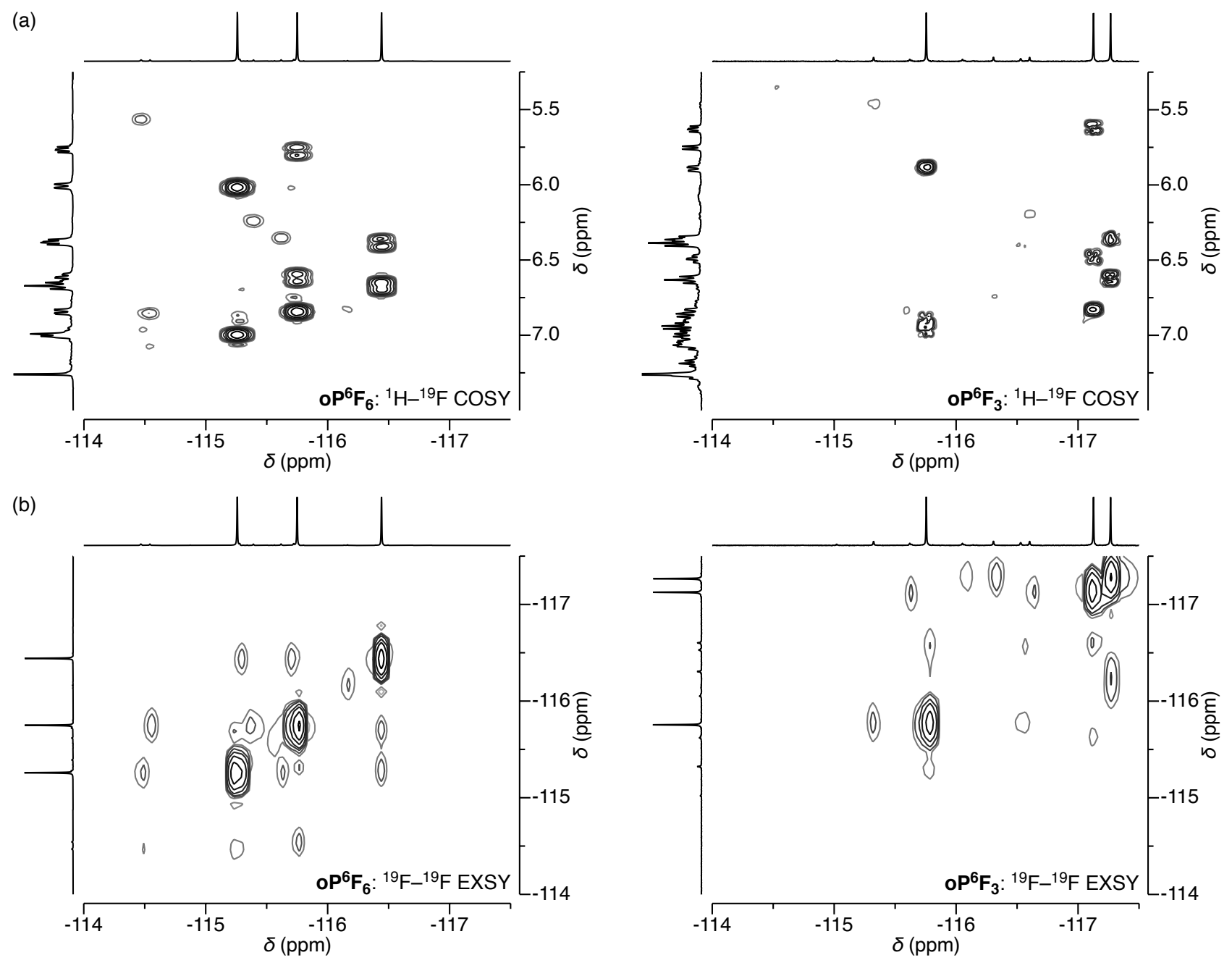

Figure 4: (a) ${ }^{19} \mathrm{~F}-{ }^{1} \mathrm{H}$ hetero-COSY spectra of $\mathbf{o P}^{\mathbf{6}} \mathbf{F}_{\mathbf{6}}$ (left) and $\mathbf{o P}^{\mathbf{6}} \mathbf{F}_{\mathbf{3}}$ (right) at $0{ }^{\circ} \mathrm{C}$. (b) ${ }^{19} \mathrm{~F}-{ }^{19} \mathrm{~F}$ EXSY NMR spectra of $\mathbf{o P}^{\mathbf{6}} \mathbf{F}_{\mathbf{6}}$ (left) and $\mathbf{o} \mathbf{P}^{\mathbf{6}} \mathbf{F}_{\mathbf{3}}$ (right) at $0{ }^{\circ} \mathrm{C}$. 
Note that the overall proportion of misfolded geometries is higher in $\mathbf{o P}^{\mathbf{6}} \mathbf{F}_{\mathbf{3}}$ compared to $\mathbf{o P}^{\mathbf{6}} \mathbf{F}_{\mathbf{6}}$. As mentioned in the Introduction, this is an expected consequence of fluoro substitution. Electron-withdrawing substituents, including F, are known to stabilize the perfectly folded conformer of $o$-phenylenes by strengthening the arene-arene stacking interactions. ${ }^{40}$

The well-resolved singlets from ${ }^{19} \mathrm{~F}\left\{{ }^{1} \mathrm{H}\right\}$ NMR spectroscopy are clearly sensitive to $o^{-}$ phenylene folding and useful for quantifying conformer populations. ${ }^{19} \mathrm{~F}$ labeling would be even more useful if predicted ${ }^{19} \mathrm{~F}$ isotropic shieldings could be used on their own to determine $o$-phenylene geometries. Fluorine isotropic shieldings were therefore calculated at the GIAO/PCM/B3LYP/6-31+G(d,p)//B97-D/cc-pVDZ level, following recommendations from Tantillo, ${ }^{50}$ for every possible geometry (AAA, AAB, ABB, BAB, and BBB). Plots of the computed isotropic shielding values $\sigma$ against the experimental chemical shifts $\delta$ for $\mathbf{o P}^{\mathbf{6}} \mathbf{F}_{\mathbf{6}}$ are shown in Figure 5 for both the major and minor conformations identified in solution, which ${ }^{1} \mathrm{H}$ NMR spectroscopy and crystallography had already determined to be the AAA and AAB states (Figure 3c). In both cases, the best matches (as indicated by an inverse linear relationship) are indeed to the previously identified geometries, suggesting that predicted ${ }^{19} \mathrm{~F}$ isotropic shieldings are of use in assigning folding states. However, there is an important caveat. The slopes of these plots, which should be close to -1 , are too steep $(-4.5$ and -2.4$)$. The issue is likely the very narrow chemical shift range of the ${ }^{19} \mathrm{~F}$ nuclei $(-115.0$ to -118.0 ppm). Results for $\mathbf{o P}^{\mathbf{6}} \mathbf{F}_{\mathbf{3}}$ are shown in the Supporting Information. Again the ${ }^{19} \mathrm{~F}$ chemical shifts correctly determine the major conformer to be AAA. However, for the minor conformer, ${ }^{19} \mathrm{~F}$ chemical shift analysis by itself could not distinguish the AAB and ABB geometries.

Overall, the analysis of these simple fluorinated $o$-phenylene hexamers shows that ${ }^{19} \mathrm{~F}$ NMR spectroscopy can be helpful in assisting ${ }^{1} \mathrm{H}$ NMR spectroscopy in geometry identification, but that it cannot provide unambiguous geometry assignments on its own. The series of unsymmetrical oligomers $\mathbf{o P}^{4} \mathbf{F O T f}-\mathbf{O P}^{10} \mathbf{F}_{4} \mathrm{OTf}$ provides a further test. Crystallography again provides initial insights into their behavior. Single crystals of $\mathbf{o P}^{\mathbf{6}} \mathbf{F}_{\mathbf{2}} \mathbf{O} \mathbf{T f}$ and $\mathbf{o P}^{\mathbf{8}} \mathbf{F}_{\mathbf{3}} \mathbf{O T f}$ were grown by layer diffusion of dichloromethane and ethanol $\left(\mathbf{o P}^{\mathbf{1 0}} \mathbf{F}_{\mathbf{4}} \mathbf{O T f}\right.$, 


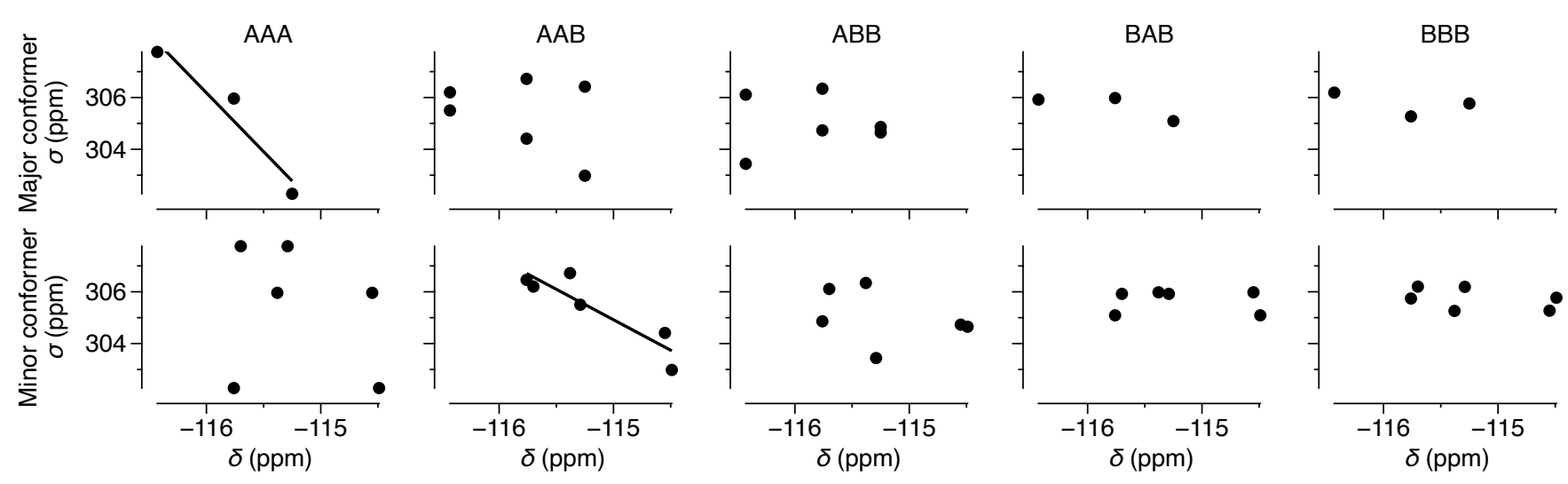

Figure 5: Computed ${ }^{19} \mathrm{~F}$ isotropic shieldings (GIAO/PCM/B3LYP/6-31+G(d,p)//B97-D/ccpVDZ) vs experimental ${ }^{19} \mathrm{~F}$ chemical shifts of the $\mathbf{o P}^{\mathbf{6}} \mathbf{F}_{\mathbf{6}}$ major conformer.

unfortunately, precipitated as a polycrystalline solid). Crystal structures are shown in Figure 6a. The $\mathbf{o P}^{\mathbf{8}} \mathbf{F}_{\mathbf{3}} \mathbf{O T f}$ crystal has a monoclinic crystal system, space group $C 2 / c$, like $\mathbf{o P}^{\mathbf{6}} \mathbf{F}_{\mathbf{6}}$ and $\mathbf{o P}^{\mathbf{6}} \mathbf{F}_{\mathbf{3}}$. In contrast, $\mathbf{o P}^{\mathbf{6}} \mathbf{F}_{\mathbf{2}} \mathbf{O} \mathbf{T f}$ crystal has the lowest-symmetry triclinic crystal system. Oligomers $\mathbf{o P}^{6} \mathbf{F}_{\mathbf{2}} \mathbf{O T f}$ and $\mathbf{o P}^{\mathbf{8}} \mathbf{F}_{\mathbf{3}} \mathbf{O T f}$ both adopt perfectly folded AAA and AAAAA geometries in the solid state. In the crystal structures, the terminal triflates point inwards, continuing the helix of the $o$-phenylene (Figure $6 \mathrm{a}$ and $6 \mathrm{~b}$ ). This is consistent with behavior observed by Aida in other well-folded ortho-functionalized $o$-phenylenes. ${ }^{21}$

The conformational behavior of $\mathbf{o P}^{4} \mathbf{F O T f}, \mathbf{o P}^{6} \mathbf{F}_{2} \mathrm{OTf}$, ${ }^{\circ} \mathbf{P}^{8} \mathbf{F}_{3} \mathrm{OTf}$, and $\mathbf{o P}^{10} \mathbf{F}_{4} \mathrm{OTf}$ was investigated using ${ }^{1} \mathrm{H}$ NMR spectroscopy. Because of their asymmetry, the 1D spectra of even the shorter triflated compounds are complex; the ${ }^{1} \mathrm{H}$ NMR spectrum of $\mathbf{o P}^{\mathbf{1 0}} \mathbf{F}_{\mathbf{4}} \mathbf{O T f}$ is shown in Figure $6 \mathrm{~b}$ as the most extreme example. The complexity makes assignment and analysis of the ${ }^{1} \mathrm{H}$ NMR signals for the major conformer challenging, but possible, using typical two-dimensional experiments (full assignments in the Supporting Information). Because the ${ }^{1} \mathrm{H}$ NMR methods serve as reference points, we again deliberately avoided using the ${ }^{19} \mathrm{~F}$ NMR spectra when making the proton assignments. It was clear, however, that it would have been very useful to work with all of the spectra at once (e.g., using the ${ }^{19} \mathrm{~F}$ signals to help identify protons).

Comparison of the ${ }^{1} \mathrm{H}$ NMR assignments with isotropic shieldings calculated for optimized 


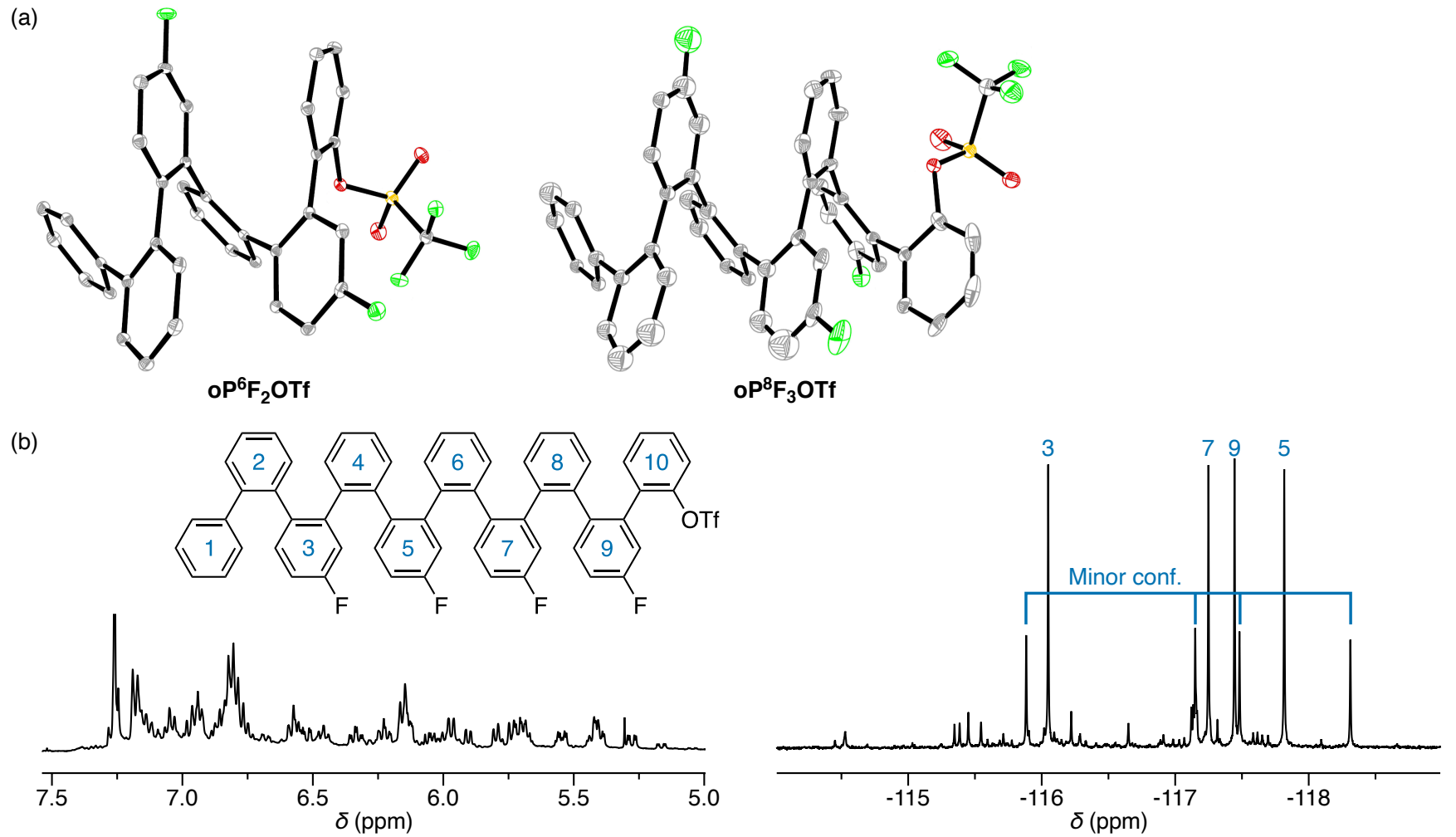

Figure 6: (a) Crystal structures of $\mathbf{o P}^{\mathbf{6}} \mathbf{F}_{\mathbf{2}} \mathbf{O T f}$ and $\mathbf{o P}^{\mathbf{8}} \mathbf{F}_{\mathbf{3}} \mathbf{O T f}$. (b) ${ }^{1} \mathrm{H}$ (left) and ${ }^{19} \mathrm{~F}$ (right) NMR spectra of $\mathbf{o P}^{10} \mathbf{F}_{4} \mathrm{OTf}$. 
geometries confirmed that all four oligomers favor their well-folded conformers in solution. The RMSDs for the matches in these cases are a bit higher than are typically found (up to $0.3 \mathrm{ppm}$ ). This likely results from the difficulty of properly accounting for the orientation of the triflate group: it can either be pointed "in" (along the helix), as observed in the solid state for $\mathbf{o P}^{6} \mathbf{F}_{2} \mathbf{O T f}$ and $\mathbf{o P}^{8} \mathbf{F}_{3} \mathbf{O T f}$, or "out". There is also the challenge of rotation about the $\mathrm{C}-\mathrm{O}$ and $\mathrm{O}-\mathrm{S}$ bonds. To better understand about the triflate orientation in solution, isotropic shielding calculations were done for each geometry and then compared with the experimental chemical shifts. Somewhat lower RMSDs are found for for the "in" geometries (0.18 vs $0.21 \mathrm{ppm}$ for $\mathbf{o} \mathbf{P}^{\mathbf{6}} \mathbf{F}_{\mathbf{2}} \mathbf{O T f}$ and 0.16 vs 0.28 ppm for $\mathbf{o P}^{8} \mathbf{F}_{\mathbf{3}} \mathbf{O T f}$, and 0.31 vs 0.32 for ${ }^{o} P^{10} F_{4} \mathbf{O T f}$ ). While not conclusive, especially for ${ }^{\circ} P^{6} F_{2} \mathrm{OTf}$ and ${ }^{\circ} \mathrm{P}^{10} \mathbf{F}_{4} \mathrm{OTf}$, a preference for the "in" geometries is consistent with the solid-state structures.

With the overall folding states determined, we assessed ${ }^{19} \mathrm{~F}$ NMR spectroscopy in these more-complicated systems. The ${ }^{19} \mathrm{~F}\left\{{ }^{1} \mathrm{H}\right\}$ NMR spectrum of $\mathbf{o P}^{\mathbf{1 0}} \mathbf{F}_{\mathbf{4}} \mathbf{O T f}$ in Figure $6 \mathrm{~b}$ is clearly less complicated and more-easily interpreted than the ${ }^{1} \mathrm{H}$ spectrum. The major fluorine signals could be assigned using ${ }^{1} \mathrm{H}-{ }^{19} \mathrm{~F}$ hetero-COSY spectroscopy. Two principal sets of signals are apparent, along with sets of much smaller signals. ${ }^{19} \mathrm{~F}-{ }^{19} \mathrm{~F}$ EXSY spectroscopy again confirmed that these are from different conformers and not impurities. Integration gives a ratio of major:minor conformers of 70:30.

The minor conformers found for this series of oligomers could result from either misfolding of the backbones (e.g., AAB instead of AAA for $\mathbf{o P}^{\mathbf{6}} \mathbf{F}_{\mathbf{2}} \mathbf{O T f}$ ) or reorientation of the triflate groups (i.e., "out" instead of "in"). The evidence suggests the latter: they are still well-folded but with the other triflate orientation. First, previous work with o-phenylenes terminated with para triflate groups found that rotation about the terminal aryl bond was slow enough to be observed by low-temperature NMR. ${ }^{40}$ Rotation about the analogous bond in these compounds should be slower (because of increased steric congestion). Splitting of the signals was not observed for $\mathbf{o P}^{\mathbf{6}} \mathbf{F}_{\mathbf{2}} \mathbf{O T f}$ at temperatures as low as $-48{ }^{\circ} \mathrm{C}$, suggesting that this bond is already slowly exchanging at $0{ }^{\circ} \mathrm{C}$. Second, the ${ }^{1} \mathrm{H}$ chemical shifts for the protons 
in the minor conformer, easily identified by ${ }^{19} \mathrm{~F}-{ }^{1} \mathrm{H}$ COSY spectra, are similar to those in the major conformer. Previous experience with o-phenylenes indicates that misfolding of the backbone would be expected to give much larger changes in ${ }^{1} \mathrm{H}$ shifts.

Plots of the ${ }^{19} \mathrm{~F}$ isotropic shieldings calculated for these compounds against the experimental chemical shifts are given in the Supporting Information. Good inverse linear relationships, with slopes close to -1 , are found, mostly because of the increased chemical shift dispersion when the triflate is included. The aromatic ${ }^{19} \mathrm{~F}$ NMR chemical shifts do not, however, differentiate the best geometries on their own as all of the plots are very similar regardless of candidate geometry.

Taken together, the results show that ${ }^{19} \mathrm{~F}$ labeling is of significant value when characterizing $o$-phenylene folding. The ${ }^{19} \mathrm{~F}$ chemical shifts are clearly sensitive to conformation. As a result, the much simpler one-dimensional ${ }^{19} \mathrm{~F}\left\{{ }^{1} \mathrm{H}\right\}$ spectra are very useful for quantifying conformational populations. Moreover, while not explicitly addressed here, it was obvious that ${ }^{19} \mathrm{~F}$-based spectra will be very helpful in combination with ${ }^{1} \mathrm{H}$ spectra when making initial chemical shift assignments. As work in this area moves toward increasingly complex, dynamic systems ${ }^{28,51}$ the ability to label key sites on $o$-phenylene backbones and monitor changes in folding should be of great use. That said, we stress that ${ }^{19} \mathrm{~F}$ shielding predictions - at least at the level of theory used here- should not be used on their own to assign geometries to o-phenylene conformations (or those of other sterically congested polyphenylenes), although they may be useful in combination with other data.

Since oligomers $\mathbf{o P}^{4} \mathbf{F O T f}-\mathbf{o P}{ }^{10} \mathbf{F}_{4} \mathbf{O T f}$ constitute a new homologous series of $o$-phenylenes, we also analyzed their photophysical properties. Shown in the Supporting Information, the UV-vis and fluorescence spectra of these compounds did not change significantly with the number of repeat units, with a slight bathochromic shift of absorbance and hypsochromic shift of emission (which is typical of $o$-phenylenes ${ }^{52}$ ). While they are formally conjugated oligomers, the extensive twisting along their backbones, when well-folded, breaks conjugation. Small shifts in absorbance spectra are therefore indicative of good folding, consistent with 
the NMR results. ${ }^{20,40}$

\section{Conclusions}

Fluorine substituents have been systematically incorporated into o-phenylene oligomers. While fluoro groups can have detrimental effects on Suzuki coupling reactions, a monomer (B4) was developed that allowed the synthesis of oligomers up to the decamer. All of the synthesized oligomers were found, by ${ }^{1} \mathrm{H}$ NMR spectroscopy and, in some cases, X-ray crystallography, to adopt well-folded conformations. Evaluation of simple hexamers $\mathbf{o P}^{\mathbf{6}} \mathbf{F}_{\mathbf{6}}$ and $\mathbf{o P}^{\mathbf{6}} \mathbf{F}_{\mathbf{3}}$ shows that ${ }^{19} \mathrm{~F}$ chemical shifts are sensitive to backbone conformation and very useful for detecting less-significant conformers. ${ }^{19} \mathrm{~F}$ NMR spectroscopy was similarly useful for the more-complex series of oligomers $\mathbf{o P}^{4} \mathbf{F O T f}-\mathbf{o P}^{10} \mathbf{F}_{4} \mathbf{O T f}$.

Overall, the results show that (1) the fluoro group is a useful substituent on $o$-phenylenes, promoting good folding; (2) ${ }^{19} \mathrm{~F}$ NMR spectra complement ${ }^{1} \mathrm{H}$ spectra when evaluating increasingly complex o-phenylenes; (3) ${ }^{19} \mathrm{~F}\left\{{ }^{1} \mathrm{H}\right\}$ NMR spectra are particularly useful for quantifying folding populations; but (4) ${ }^{19} \mathrm{~F}$ isotropic shielding predictions, at least using current methods, should not be used by themselves to determine $o$-phenylene geometries.

\section{Experimental}

\section{General}

Unless otherwise noted, all starting materials, reagents, and solvents were purchased from commercial sources and used without further purification. Melting points were determined using a Thermal Analysis Q20 differential scanning calorimeter at a heating rate of $10{ }^{\circ} \mathrm{C} / \mathrm{min}$. NMR spectra were measured in $\mathrm{CDCl}_{3}$ and acetone- $d_{6}$ solvents using $200 \mathrm{MHz}, 400 \mathrm{MHz}$, and $500 \mathrm{MHz}$ spectrometers. Semi-preparative gel permeation chromatography was performed

using $100 \AA$ and $500 \AA$ polystyrene-divinylbenzene columns $(300 \times 21.2 \mathrm{~mm})$ with toluene 
as the eluant at $5 \mathrm{~mL} / \mathrm{min}$.

\section{General procedure for the synthesis of fluorophenylphenols}

Iodophenol (28 mmol, 1.00 equiv) and 3-fluoroboronic acid (43 mmol, 1.50 equiv) were added to a dry $250 \mathrm{~mL}$ round-bottomed flask under argon. Toluene $(40 \mathrm{~mL})$, ethanol $(6.25 \mathrm{~mL})$, and $2 \mathrm{M} \mathrm{Na}_{2} \mathrm{CO}_{3}(\mathrm{aq})(10 \mathrm{~mL})$ were added and the flask purged with argon for $10 \mathrm{~min}$. $\mathrm{Pd}\left(\mathrm{PPh}_{3}\right)_{4}$ (1.40 mmol, 0.05 equiv) was added in one portion and the reaction mixture heated to $90{ }^{\circ} \mathrm{C}$ under argon overnight. The reaction mixture was then cooled to rt and diluted with EtOAc (20 mL). $1 \mathrm{M} \mathrm{HCl}(\mathrm{aq})$ (20 mL) was added and the aqueous layer extracted with EtOAc (3 $\times 30 \mathrm{~mL}$ ). The combined organic layers were washed with water and brine, then dried over anhydrous $\mathrm{MgSO}_{4}$, filtered, and concentrated. Purification was done by flash chromatography (EtOAc:hexanes 1:9).

\section{2-(3-Fluorophenyl)phenol}

The general procedure was followed using 2-iodophenol (6.66 g, $28 \mathrm{mmol}$ ) and 3-fluoroboronic acid (6.00 g, $43 \mathrm{mmol})$. 2-(3-Fluorophenyl)phenol was obtained as a colorless liquid (3.91 g, 75\%): ${ }^{1} \mathrm{H}$ NMR $\left(500 \mathrm{MHz}, \mathrm{CDCl}_{3}\right) \delta 7.45(\mathrm{td}, J=7.9,6.0 \mathrm{~Hz}, 1 \mathrm{H}), 7.34-7.28(\mathrm{~m}, 2 \mathrm{H})$, 7.28-7.22 (m, 2H), 7.10 (tdd, $J=8.5,2.7,1.0 \mathrm{~Hz}, 1 \mathrm{H}), 7.04$ (td, $J=7.5,1.2 \mathrm{~Hz}, 1 \mathrm{H})$, 7.01-6.96 (m, 1H); ${ }^{13} \mathrm{C}\left\{{ }^{1} \mathrm{H}\right\} \operatorname{NMR}\left(126 \mathrm{MHz}, \mathrm{CDCl}_{3}\right) \delta 164.2,162.2,152.4,139.7,139.6$, 130.6, 130.6, 130.4, 129.7, 129.6, 127.2, 127.1, 124.8, 124.8, 121.1, 120.8, 116.4, 116.3, 116.2, 115.4, 114.7, 114.6; ${ }^{19} \mathrm{~F}\left\{{ }^{1} \mathrm{H}\right\}$ NMR (188 MHz, $\left.\mathrm{CDCl}_{3}\right) \delta-112.1$; HRMS (ESI-Orbitrap) $m / z$ $\left([\mathrm{M}-\mathrm{H}]^{+}\right)$calcd for $\mathrm{C}_{12} \mathrm{H}_{8} \mathrm{FO} 187.0559$, found 187.0569.

\section{3',5-Difluorobiphenyl-2-ol}

The general procedure was followed using 2-iodo-4-fluorophenol ${ }^{53}$ (6.16 g, $\left.28 \mathrm{mmol}\right)$ and 3-fluoroboronic acid (6.00 g, $43 \mathrm{mmol})$ ). 3',5-Difluorobiphenyl-2-ol was obtained as a red liquid (4.26 g, 74\%): $\left.{ }^{1} \mathrm{H} \mathrm{NMR} \mathrm{(400} \mathrm{MHz} \mathrm{CDCl}_{3}\right) \delta 7.48(\mathrm{ddd}, J=13.9,6.4,4.3 \mathrm{~Hz}, 1 \mathrm{H})$, 
7.35-7.19 (m, 2H), $7.13(\mathrm{td}, J=8.5,2.7 \mathrm{~Hz}, 1 \mathrm{H}), 7.05-6.83(\mathrm{~m}, 3 \mathrm{H}) ;{ }^{13} \mathrm{C}\left\{{ }^{1} \mathrm{H}\right\}$ NMR $(101$ $\left.\mathrm{MHz}, \mathrm{CDCl}_{3}\right) \delta 163.1(\mathrm{~d}, J=247.2 \mathrm{~Hz}), 157.2(\mathrm{~d}, J=238.8 \mathrm{~Hz}), 148.4(\mathrm{~d}, J=2.2 \mathrm{~Hz})$, $138.7(\mathrm{dd}, J=7.8,1.7 \mathrm{~Hz}), 130.7(\mathrm{~d}, J=8.4 \mathrm{~Hz}), 129.2(\mathrm{~d}, J=31.6 \mathrm{~Hz}), 128.60-127.2$ $(\mathrm{m}), 124.7(\mathrm{~d}, J=3.0 \mathrm{~Hz}), 117.2(\mathrm{~d}, J=8.2 \mathrm{~Hz}), 116.5(\mathrm{~d}, J=23.6 \mathrm{~Hz}), 116.2(\mathrm{~d}, J=21.9$ $\mathrm{Hz}), 115.8(\mathrm{~d}, J=22.9 \mathrm{~Hz}), 115.1(\mathrm{~d}, J=21.1 \mathrm{~Hz}) ;{ }^{19} \mathrm{~F}\left\{{ }^{1} \mathrm{H}\right\} \mathrm{NMR}\left(376 \mathrm{MHz}, \mathrm{CDCl}_{3}\right) \delta$ -111.6, -123.4; HRMS (ESI-Orbitrap) $m / z\left([\mathrm{M}-\mathrm{H}]^{+}\right.$) calcd for $\mathrm{C}_{12} \mathrm{H}_{7} \mathrm{~F}_{2} \mathrm{O}$ 205.0465, found 205.0469 .

\section{General procedure for the synthesis of fluoroboroxarenes B1, B2,}

\section{B3 and B4}

An oven-dried $250 \mathrm{~mL}$ two-necked round-bottom flask, equipped with an argon stream and sealed with a septum, was charged with a $0.35 \mathrm{M}$ solution of $\mathrm{BCl}_{3}$ in hexanes. The appropriate fluorinated 2-phenylphenols in anhydrous hexanes (0.25 M, 1.00 equiv) was added slowly via syringe. The reaction mixture was stirred at $\mathrm{rt}$ for 5-10 min, then $\mathrm{AlCl}_{3}$ (0.13 equiv) was added in one portion. The reaction mixture was heated to reflux overnight, then cooled to rt. Ice was added slowly to quench the reaction. Diethyl ether $(20 \mathrm{~mL})$ was added and the mixture stirred for $20 \mathrm{~min}$. The organic layer was separated and the aqueous layer extracted with diethyl ether $(3 \times 20 \mathrm{~mL})$. The combined organic layers were washed with $\mathrm{H}_{2} \mathrm{O}(20 \mathrm{~mL})$ and brine $(20 \mathrm{~mL})$, then dried over anhydrous $\mathrm{MgSO}_{4}$, filtered, and concentrated.

\section{2,9-Difluorodibenzo $[c, e][1,2]$ oxaborinin-6-ol (B1)}

The general procedure was followed using 3',5-difluorobiphenyl-2-ol (1.88 g, $9.14 \mathrm{mmol})$. Recrystallization from $\mathrm{CH}_{2} \mathrm{Cl}_{2}$ gave $\mathrm{B} 1$ as a white solid (1.23 g, 58\%): m.p. $241.01{ }^{\circ} \mathrm{C}$ (dec.); ${ }^{1} \mathrm{H}$ NMR $\left(500 \mathrm{MHz}\right.$, acetone- $\left.d_{6}\right) \delta 8.32(\mathrm{~s}, 1 \mathrm{H}), 8.16(\mathrm{dd}, J=8.25,6.65 \mathrm{~Hz}, 1 \mathrm{H}), 8.00(\mathrm{dd}, J$ $=11.25,2.3 \mathrm{~Hz}, 1 \mathrm{H}), 7.97(\mathrm{dd}, J=10.1,3.0 \mathrm{~Hz}, 1 \mathrm{H}), 7.29(\mathrm{td}, J=8.5,2.3 \mathrm{~Hz}, 1 \mathrm{H}), 7.25$ $(\mathrm{dd}, J=8.95,5.05 \mathrm{~Hz}, 1 \mathrm{H}), 7.19(\mathrm{~m}, 1 \mathrm{H}) ;{ }^{13} \mathrm{C}\left\{{ }^{1} \mathrm{H}\right\}\left(126 \mathrm{MHz}\right.$, acetone- $\left.d_{6}\right) \delta 165.9(\mathrm{~d}, J=$ $249 \mathrm{~Hz}), 158.2(\mathrm{~d}, J=238 \mathrm{~Hz}), 148.1(\mathrm{~d}, J=1.8 \mathrm{~Hz}), 142.5(\mathrm{~d}, J=2.8 \mathrm{~Hz}), 142.4(\mathrm{~d}, J$ 
$=1.8 \mathrm{~Hz}), 136.3(\mathrm{~d}, J=9.3 \mathrm{~Hz}), 123.3(\mathrm{~d}, J=2.8 \mathrm{~Hz}), 120.8(\mathrm{~d}, J=8.3 \mathrm{~Hz}), 116.4(\mathrm{~d}, J$ $=24.1 \mathrm{~Hz}), 115.3(\mathrm{~d}, J=22.2 \mathrm{~Hz}), 109.9(\mathrm{~d}, J=25 \mathrm{~Hz}), 108.6(\mathrm{~d}, J=22.2 \mathrm{~Hz}) ;{ }^{19} \mathrm{~F}\left\{{ }^{1} \mathrm{H}\right\}$ $\left(188 \mathrm{MHz}\right.$, acetone- $\left.d_{6}\right) \delta-107.8,-122.0$; HRMS (ESI-Orbitrap) $\mathrm{m} / z\left([\mathrm{M}-\mathrm{H}]^{+}\right)$calcd for $\mathrm{C}_{12} \mathrm{H}_{6} \mathrm{BF}_{2} \mathrm{O}_{2} 231.0429$, found 231.0442 .

\section{2-Fluorodibenzo[c,e][1,2] oxaborinin-6-ol (B2)}

The general procedure was followed using 5-fluorobiphenyl-2-ol ${ }^{54}(1.26 \mathrm{~g}, 6.71 \mathrm{mmol})$. Recrystallization from hexanes gave $\mathbf{B} 2$ as a white solid (1.10 g, 78\%): m.p. $197.84{ }^{\circ} \mathrm{C}$ (dec.); ${ }^{1} \mathrm{H}$ NMR $\left(500 \mathrm{MHz}\right.$, acetone- $\left.d_{6}\right) \delta 8.30(\mathrm{~s}, 1 \mathrm{H}), 8.26(\mathrm{~d}, J=8.05 \mathrm{~Hz}, 1 \mathrm{H}), 8.14(\mathrm{~d}, J=7.55$ $\mathrm{Hz}, 1 \mathrm{H}), 7.97(\mathrm{dd}, J=10.3,2.95 \mathrm{~Hz}, 1 \mathrm{H}), 7.75(\mathrm{td}, J=8.5,1.15 \mathrm{~Hz}, 1 \mathrm{H}), 7.53(\mathrm{t}, J=7.35$ $\mathrm{Hz}, 1 \mathrm{H}), 7.25(\mathrm{dd}, J=8.95,5.05 \mathrm{~Hz}, 1 \mathrm{H}), 7.15(\mathrm{td}, J=8.05,3.0 \mathrm{~Hz}, 1 \mathrm{H}) ;{ }^{13} \mathrm{C}\left\{{ }^{1} \mathrm{H}\right\}(126$ MHz, acetone- $\left.d_{6}\right) \delta 159.2(\mathrm{~d}, J=238 \mathrm{~Hz}), 148.7,140.4,133.4,133.4,128.8,125.0(\mathrm{~d}, J=$ $7.56 \mathrm{~Hz}), 123.1,121.6(\mathrm{~d}, J=7.56), 116.6(\mathrm{~d}, J=23.9), 110.4(\mathrm{~d}, J=23.9) ;{ }^{19} \mathrm{~F}\left\{{ }^{1} \mathrm{H}\right\}(188$ $\mathrm{MHz}$, acetone- $\left.d_{6}\right) \delta-122.3$; HRMS (ESI-Orbitrap) $m / z\left([\mathrm{M}-\mathrm{H}]^{+}\right)$calcd for for $\mathrm{C}_{12} \mathrm{H}_{7} \mathrm{BFO}_{2}$ 213.0523, found 213.0529.

\section{3,8-Difluorodibenzo $[c, e][1,2]$ oxaborinin-6-ol (B3)}

The general procedure was followed using $4^{\prime}, 4$-difluorobiphenyl-2-ol. ${ }^{55}$ Recrystallization from hexanes gave B3 as a white solid (1.12 g, 78\%): m.p. $297.60{ }^{\circ} \mathrm{C}$ (dec.); ${ }^{1} \mathrm{H}$ NMR (500 MHz, acetone- $\left.d_{6}\right)^{1} \mathrm{H}$ NMR $\left(400 \mathrm{MHz}\right.$, acetone- $\left.d_{6}\right) \delta 8.57(\mathrm{~s}, 1 \mathrm{H}), 8.33(\mathrm{dd}, J=8.9,4.8 \mathrm{~Hz}, 1 \mathrm{H})$, $8.27(\mathrm{dd}, J=8.8,6.3 \mathrm{~Hz}, 1 \mathrm{H}), 7.77(\mathrm{dd}, J=8.6,2.9 \mathrm{~Hz}, 1 \mathrm{H}), 7.52(\mathrm{td}, J=8.8,2.9 \mathrm{~Hz}, 1 \mathrm{H})$, 7.08-6.97 (m, 2H); ${ }^{13} \mathrm{C}\left\{{ }^{1} \mathrm{H}\right\}\left(101 \mathrm{MHz}\right.$, acetone- $\left.d_{6}\right) \delta 164.4(\mathrm{~d}, J=93.4 \mathrm{~Hz}), 161.9(\mathrm{~d}, J$ $=94.5 \mathrm{~Hz}), 137.2,126.3(\mathrm{~d}, J=10.1 \mathrm{~Hz}), 125.5(\mathrm{~d}, J=7.5 \mathrm{~Hz}), 121.0(\mathrm{~d}, J=22.8 \mathrm{~Hz})$, $119.2(\mathrm{~d}, J=19.2 \mathrm{~Hz}), 110.8(\mathrm{~d}, J=21.9 \mathrm{~Hz}), 107.0(\mathrm{~d}, J=24.0 \mathrm{~Hz}) ;{ }^{19} \mathrm{~F}\left\{{ }^{1} \mathrm{H}\right\}(376 \mathrm{MHz}$, acetone- $\left.d_{6}\right) \delta-114.2,-116.1(\mathrm{~d}, J=2.1 \mathrm{~Hz})$; HRMS (ESI-Orbitrap) $m / z\left([\mathrm{M}-\mathrm{H}]^{-}\right)$calcd for $\mathrm{C}_{12} \mathrm{H}_{6} \mathrm{BF}_{2} \mathrm{O}_{2} 231.0434$, found 231.0432. 


\section{9-Fluorodibenzo $[c, e][1,2]$ oxaborinin-6-ol (B4)}

The general procedure was followed using 2-(3-fluorophenyl)phenol (1.31 g, $7.00 \mathrm{mmol})$. Recrystallization from hexanes gave $\mathbf{B} 4$ as a white solid $(1.41 \mathrm{~g}, 94 \%)$ : m.p. $143.10{ }^{\circ} \mathrm{C}$ (dec.); ${ }^{1} \mathrm{H}$ NMR (500 MHz, acetone- $\left.d_{6},\right) \delta 8.29(\mathrm{~s}, 1 \mathrm{H}), 8.27-8.23(\mathrm{~m}, 1 \mathrm{H}), 8.18(\mathrm{dd}, J=8.3,6.6 \mathrm{~Hz}$, $1 \mathrm{H}), 8.03(\mathrm{dd}, J=11.5,2.3 \mathrm{~Hz}, 1 \mathrm{H}), 7.44(\mathrm{ddd}, J=8.4,7.1,1.6 \mathrm{~Hz}, 1 \mathrm{H}), 7.30-7.23(\mathrm{~m}, 3 \mathrm{H})$; ${ }^{13} \mathrm{C}\left\{{ }^{1} \mathrm{H}\right\}\left(126 \mathrm{MHz}\right.$,acetone- $\left.d_{6}\right) \delta 166.9(\mathrm{~d}, J=248 \mathrm{MHz}), 152.8,144.3(\mathrm{~d}, J=8.8 \mathrm{MHz})$ $137.3(\mathrm{~d}, J=9.1 \mathrm{MHz}), 130.7,125.1,123.5,123.0,120.4,115.6(\mathrm{~d}, J=21.6 \mathrm{MHz}), 109.0$ $(\mathrm{d}, J=22.2 \mathrm{MHz}) ;{ }^{19} \mathrm{~F}\left\{{ }^{1} \mathrm{H}\right\}\left(188 \mathrm{MHz}\right.$, acetone- $\left.d_{6}\right) \delta$-108.1; HRMS (ESI-Orbitrap) $\mathrm{m} / z$ $\left([\mathrm{M}-\mathrm{H}]^{+}\right)$calcd for $\mathrm{C}_{12} \mathrm{H}_{7} \mathrm{BFO}_{2} 213.0523$, found 213.1667.

\section{General procedure for oligomer elongation by Suzuki coupling and triflation}

An oven-dried Schlenk vacuum tube was charged with fluoroboroxarene (1.50 equiv), aryl triflate (1.00 equiv), $\mathrm{Pd}(\mathrm{OAc})_{2}$ (0.20 equiv), SPhos (0.30 equiv), $\mathrm{K}_{3} \mathrm{PO}_{4}$ (3.00 equiv), and 2:1 THF $/ \mathrm{H}_{2} \mathrm{O}(2 / 1)$ such that the concentration of (pseudo)halogen was $0.5 \mathrm{M}$. The mixture was degassed by three freeze-pump-thaw cycles and filled with argon. It was then heated for $24 \mathrm{~h}$, cooled to rt, and partitioned between with EtOAc $(10 \mathrm{~mL})$ and $1 \mathrm{M} \mathrm{HCl}(10 \mathrm{~mL})$. The aqueous layer was extracted with EtOAc $(3 \times 10 \mathrm{~mL})$. The combined organic layers were washed with water and brine, dried over $\mathrm{MgSO}_{4}$, filtered, and concentrated. The phenol was purified by flash chromatography (7:3 hexanes:EtOAc). It was dissolved in $\mathrm{CH}_{2} \mathrm{Cl}_{2}(5.0 \mathrm{~mL})$, treated with pyridine ( 5 equiv), and cooled to $0{ }^{\circ} \mathrm{C}$. After $10 \mathrm{~min}$, trifluoromethanesulfonic anhydride (1.5 equiv) was added dropwise. The reaction was allowed to warm to rt overnight. It was carefully diluted with EtOAc $(10 \mathrm{~mL})$, washed with $1 \mathrm{M} \mathrm{HCl}(\mathrm{aq})(10 \mathrm{~mL})$, water $(10$ $\mathrm{mL})$, and brine $(10 \mathrm{~mL})$, then dried over $\mathrm{MgSO}_{4}$, filtered, and concentrated. The products were isolated by flash chromatography (9:1 hexanes:EtOAc). 


\section{Oligomer oP ${ }^{3} \mathrm{~F}_{2} \mathrm{OTf}$}

The general procedure was followed using 4-fluorobromobenzene (613 mg, $3.50 \mathrm{mmol}$ ) and B2 (1.12 g, $5.25 \mathrm{mmol})$ ) at $90-95{ }^{\circ} \mathrm{C}$, giving $\mathbf{o P}^{\mathbf{3}} \mathbf{F}_{\mathbf{2}} \mathbf{O T f}$ as a white solid (886 $\left.\mathrm{mg}, 61 \%\right)$ : m.p. $64.72{ }^{\circ} \mathrm{C}$ (dec.); ${ }^{1} \mathrm{H}$ NMR $\left(400 \mathrm{MHz} \mathrm{CDCl}_{3}\right) \delta 7.57-7.36(\mathrm{~m}, 4 \mathrm{H}), 7.14-6.99$ (m, 5H), $6.92(\mathrm{t}, 2 \mathrm{H}) ;{ }^{13} \mathrm{C}\left\{{ }^{1} \mathrm{H}\right\} \operatorname{NMR}\left(101 \mathrm{MHz}, \mathrm{CDCl}_{3}\right) \delta 162.8(\mathrm{~d}, J=80.4 \mathrm{~Hz}), 160.3(\mathrm{~d}, J=83.7$ Hz), $142.2(\mathrm{~d}, J=3.0 \mathrm{~Hz}), 140.6,137.4$ (d, $J=8.6 \mathrm{~Hz}), 136.5(\mathrm{~d}, J=3.3 \mathrm{~Hz}), 132.9,131.2$, $130.9(\mathrm{~d}, J=8.0 \mathrm{~Hz}), 130.4,129.5,127.7,123.4(\mathrm{~d}, J=9.3 \mathrm{~Hz}), 119.4(\mathrm{~d}, J=23.9 \mathrm{~Hz})$, $116.0(\mathrm{~d}, J=23.8 \mathrm{~Hz}), 115.1(\mathrm{~d}, J=21.4 \mathrm{~Hz}) ;{ }^{19} \mathrm{~F}\left\{{ }^{1} \mathrm{H}\right\} \operatorname{NMR}\left(376 \mathrm{MHz}, \mathrm{CDCl}_{3}\right) \delta-74.3$, -112.2,-115.4; HRMS (ESI-FT-ICR) $m / z\left([\mathrm{M}+\mathrm{Na}]^{+}\right)$calcd for $\mathrm{C}_{19} \mathrm{H}_{11} \mathrm{~F}_{5} \mathrm{O}_{3} \mathrm{SNa} 437.02412$, found 437.02406 .

\section{Oligomer oP ${ }^{3} \mathrm{~F}_{3} \mathrm{OTf}$}

The general procedure was followed using 4-fluorobromobenzene (346 mg, $1.98 \mathrm{mmol}$ ) and B1 (689 $\mathrm{mg}, 2.97 \mathrm{mmol})$ ) at $90-95{ }^{\circ} \mathrm{C}$, giving $\mathbf{o P}^{\mathbf{3}} \mathbf{F}_{\mathbf{3}} \mathbf{O} \mathbf{T f}$ as a white solid (480 $\left.\mathrm{mg}, 56 \%\right)$ : m.p. $84.99{ }^{\circ} \mathrm{C}$ (dec.); ${ }^{1} \mathrm{H}$ NMR $\left(400 \mathrm{MHz}, \mathrm{CDCl}_{3}\right) \delta 7.40(\mathrm{dd}, J=8.6,5.6 \mathrm{~Hz}, 1 \mathrm{H}), 7.22(\mathrm{td}, J=$ 8.3, $2.7 \mathrm{~Hz}, 1 \mathrm{H}), 7.15-7.01(\mathrm{~m}, 6 \mathrm{H}), 6.95-6.88(\mathrm{~m}, 2 \mathrm{H}) ;{ }^{13} \mathrm{C}\left\{{ }^{1} \mathrm{H}\right\}$ NMR $\left(101 \mathrm{MHz}, \mathrm{CDCl}_{3}\right) \delta$ $163.2(\mathrm{~d}, J=22.5 \mathrm{~Hz}), 162.4,160.7(\mathrm{~d}, J=24.0 \mathrm{~Hz}), 160.0,142.03(\mathrm{~d}, J=3.1 \mathrm{~Hz}), 136.9$ $(\mathrm{d}, J=3.4 \mathrm{~Hz}), 136.3(\mathrm{dd}, J=8.6,1.8 \mathrm{~Hz}), 135.5(\mathrm{~d}, J=3.3 \mathrm{~Hz}), 134.6(\mathrm{~d}, J=8.1 \mathrm{~Hz})$, $132.2(\mathrm{~d}, J=8.2 \mathrm{~Hz}), 131.0(\mathrm{~d}, J=8.2 \mathrm{~Hz}), 123.7(\mathrm{~d}, J=9.3 \mathrm{~Hz}), 119.3(\mathrm{~d}, J=24.0 \mathrm{~Hz})$, $118.0(\mathrm{~d}, J=22.6 \mathrm{~Hz}), 116.7(\mathrm{~d}, J=5.8 \mathrm{~Hz}), 116.4(\mathrm{~d}, J=2.9 \mathrm{~Hz}), 115.2(\mathrm{~d}, J=21.4 \mathrm{~Hz})$; ${ }^{19} \mathrm{~F}\left\{{ }^{1} \mathrm{H}\right\}$ NMR $\left(376 \mathrm{MHz}, \mathrm{CDCl}_{3}\right) \delta-74.2,-111.7,-114.5,-115.1$; HRMS (ESI-Orbitrap) $m / z\left([\mathrm{M}]^{+}\right)$calcd for $\mathrm{C}_{19} \mathrm{H}_{10} \mathrm{~F}_{6} \mathrm{O}_{3} \mathrm{~S} 432.0258$, found 432.0287 .

\section{Oligomer oP ${ }^{5} \mathrm{~F}_{3} \mathrm{OTf}$}

The general procedure was followed using $\mathbf{o P}^{\mathbf{3}} \mathbf{F}_{\mathbf{2}} \mathbf{O T f}(531 \mathrm{mg}, 1.28 \mathrm{mmol}$ ) and $\mathbf{B} 2$ (411 $\mathrm{mg}$, $1.92 \mathrm{mmol})$ ) at $90-95^{\circ} \mathrm{C}$, giving $\mathbf{O P}^{\mathbf{5}} \mathbf{F}_{\mathbf{3}} \mathbf{O} \mathbf{T f}$ as a white solid (180 $\left.\mathrm{mg}, 24 \%\right)$ : m.p. 163.71 ${ }^{\circ} \mathrm{C}$ (dec.); ${ }^{1} \mathrm{H}$ NMR (400 MHz, $\left.\mathrm{CDCl}_{3}\right) \delta 7.28$ (dd, $\left.J=13.8,6.3 \mathrm{~Hz}, 1 \mathrm{H}\right), 7.23-7.15$ (m, 1H), 
7.14-7.00 (m, 5H), 6.99-6.88 (m, 4H), $6.72(\mathrm{t}, J=8.6 \mathrm{~Hz}, 2 \mathrm{H}), 6.46(\mathrm{dd}, J=8.4,5.4 \mathrm{~Hz}$, $2 \mathrm{H}), 6.31(\mathrm{~d}, J=7.6 \mathrm{~Hz}, 1 \mathrm{H}), 6.13(\mathrm{~d}, J=7.7 \mathrm{~Hz}, 1 \mathrm{H}), 5.99-5.89(\mathrm{~m}, 1 \mathrm{H}) ;{ }^{13} \mathrm{C}\left\{{ }^{1} \mathrm{H}\right\} \mathrm{NMR}$ $\left(101 \mathrm{MHz}, \mathrm{CDCl}_{3}\right) \delta 163.6,162.8(\mathrm{~d}, J=34.8 \mathrm{~Hz}), 161.1,160.3(\mathrm{~d}, J=37.2 \mathrm{~Hz}), 141.9(\mathrm{~d}$, $J=2.8 \mathrm{~Hz}), 141.7(\mathrm{~d}, J=7.6 \mathrm{~Hz}), 139.5(\mathrm{~d}, J=110.8 \mathrm{~Hz}), 138.0,137.3(\mathrm{~d}, J=8.9 \mathrm{~Hz})$, $136.7(\mathrm{~d}, J=3.2 \mathrm{~Hz}), 136.1(\mathrm{~d}, J=3.2 \mathrm{~Hz}), 134.5(\mathrm{~d}, J=8.3 \mathrm{~Hz}), 133.1,131.6(\mathrm{~d}, J=18.1$ $\mathrm{Hz}), 130.6,130.2(\mathrm{~d}, J=8.1 \mathrm{~Hz}), 130.0,129.4,127.8(\mathrm{~d}, J=12.7 \mathrm{~Hz}), 126.9,122.4(\mathrm{~d}, J$ $=9.5 \mathrm{~Hz}), 119.7,119.0(\mathrm{~d}, J=23.7 \mathrm{~Hz}), 117.6(\mathrm{~d}, J=21.5 \mathrm{~Hz}), 115.3(\mathrm{~d}, J=23.8 \mathrm{~Hz})$, $114.9(\mathrm{~d}, J=21.2 \mathrm{~Hz}), 114.7(\mathrm{~d}, J=20.8 \mathrm{~Hz}) ;{ }^{19} \mathrm{~F}\left\{{ }^{1} \mathrm{H}\right\}$ NMR $\left(376 \mathrm{MHz}, \mathrm{CDCl}_{3}\right) \delta-74.3$, $-112.3,-115.0,-116.5$; HRMS (LDI-FT-ICR) $m / z\left([\mathrm{M}+\mathrm{Na}]^{+}\right)$calcd for $\mathrm{C}_{31} \mathrm{H}_{18} \mathrm{~F}_{6} \mathrm{O}_{3} \mathrm{SNa}$ 607.07730, found 607.07707.

\section{Oligomer oP ${ }^{5} \mathrm{~F}_{5} \mathrm{OTf}$}

The general procedure was followed using $\mathbf{o P}^{\mathbf{3}} \mathbf{F}_{\mathbf{3}} \mathbf{O T f}(491 \mathrm{mg}, 1.14 \mathrm{mmol})$ and $\mathbf{B} 1$ (397 $\mathrm{mg}$, $1.71 \mathrm{mmol})$ ) at $90-95{ }^{\circ} \mathrm{C}$, giving $\mathbf{o P} \mathbf{P}^{5} \mathbf{F}_{5} \mathbf{O T f}$ as a white solid $(268 \mathrm{mg}, 38 \%)$ : m.p. $168.65{ }^{\circ} \mathrm{C}$ (dec.); ${ }^{1} \mathrm{H}$ NMR (400 MHz, $\left.\mathrm{CDCl}_{3}\right) \delta$ 7.22-7.09 (m, 2H), 7.06-6.92 (m, 5H), 6.80-6.68 (m, $4 \mathrm{H}), 6.48(\mathrm{ddd}, J=8.6,5.4,2.6 \mathrm{~Hz}, 2 \mathrm{H}), 6.14-6.06(\mathrm{~m}, 2 \mathrm{H}), 5.97(\mathrm{dd}, J=9.4,2.3 \mathrm{~Hz}, 1 \mathrm{H})$; ${ }^{13} \mathrm{C}\left\{{ }^{1} \mathrm{H}\right\} \operatorname{NMR}\left(101 \mathrm{MHz}, \mathrm{CDCl}_{3}\right) \delta 163.7,163.1(\mathrm{~d}, J=25.8 \mathrm{~Hz}), 162.7(\mathrm{~d}, J=3.9 \mathrm{~Hz})$, $161.2,160.7(\mathrm{~d}, J=24.4 \mathrm{~Hz}), 160.2,141.7(\mathrm{~d}, J=3.1 \mathrm{~Hz}), 140.4(\mathrm{~d}, J=7.6 \mathrm{~Hz}), 139.9(\mathrm{~d}$, $J=7.9 \mathrm{~Hz}), 136.0(\mathrm{~d}, J=3.5 \mathrm{~Hz}), 135.7(\mathrm{~d}, J=3.2 \mathrm{~Hz}), 135.0(\mathrm{~d}, J=3.3 \mathrm{~Hz}), 134.8(\mathrm{~d}, J$ $=7.9 \mathrm{~Hz}), 133.4,131.70(\mathrm{~d}, J=8.2 \mathrm{~Hz}), 130.0(\mathrm{~d}, J=8.1 \mathrm{~Hz}), 123.0(\mathrm{~d}, J=9.2 \mathrm{~Hz}), 119.7$, $118.5(\mathrm{~d}, J=24.2 \mathrm{~Hz}), 118.0(\mathrm{~d}, J=21.8 \mathrm{~Hz}), 117.6(\mathrm{~d}, J=21.8 \mathrm{~Hz}), 117.2(\mathrm{~d}, J=22.5$ Hz), $116.4(\mathrm{~d}, J=16.1 \mathrm{~Hz}), 116.2(\mathrm{~d}, J=19.2 \mathrm{~Hz}), 115.4(\mathrm{~d}, J=20.7 \mathrm{~Hz}), 115.2(\mathrm{~d}, J=$ $20.9 \mathrm{~Hz}), 115.0(\mathrm{~d}, J=21.4 \mathrm{~Hz}) ;{ }^{19} \mathrm{~F}\left\{{ }^{1} \mathrm{H}\right\} \operatorname{NMR}\left(376 \mathrm{MHz}, \mathrm{CDCl}_{3}\right) \delta-74.1,-111.9(\mathrm{~d}, \mathrm{~J}$ $=3.5 \mathrm{~Hz}),-114.1,-115.0-115.2(\mathrm{~m}),-115.3,-115.8$; HRMS (LDI-FT-ICR) $m / z([\mathrm{M}+$ $\mathrm{Na}]^{+}$) calcd for $\mathrm{C}_{31} \mathrm{H}_{16} \mathrm{~F}_{8} \mathrm{O}_{3} \mathrm{SNa}$ 643.05846, found 643.05846. 


\section{Oligomer oP ${ }^{4}$ FOTf}

The general procedure was followed using (1,1'-biphenyl)-2-yl trifluoromethanesulfonate ${ }^{56}$ (368 mg, $1.21 \mathrm{mmol})$ and $\mathbf{B} 4(388 \mathrm{mg}, 1.82 \mathrm{mmol})$ ) at $55^{\circ} \mathrm{C}$, giving $\mathbf{0} \mathbf{P}^{4} \mathbf{F O T f}$ as a semisolid (455 mg, 79\%): See Table S5 for full ${ }^{1} \mathrm{H},{ }^{13} \mathrm{C}$, and ${ }^{19} \mathrm{~F}$ assignments; HRMS (LDI-FT-ICR) $m / z\left([\mathrm{M}]^{+}\right)$calcd for $\mathrm{C}_{25} \mathrm{H}_{16} \mathrm{~F}_{4} \mathrm{O}_{3} \mathrm{~S} 472.07508$, found 472.07522 .

\section{Oligomer oP ${ }^{6} \mathrm{~F}_{2} \mathrm{OTf}$}

The general procedure was followed using oP ${ }^{4}$ FOTf (448 mg, $0.94 \mathrm{mmol}$ ) and B4 (302 mg, $1.41 \mathrm{mmol})$ at $55{ }^{\circ} \mathrm{C}$, giving $\mathbf{o} \mathbf{P}^{6} \mathbf{F}_{2} \mathbf{O T f}$ as a white solid (494 mg, 81\%): m.p. $180.06{ }^{\circ} \mathrm{C}$ (dec.); See Table S6 for full ${ }^{1} \mathrm{H},{ }^{13} \mathrm{C}$, and ${ }^{19} \mathrm{~F}$ assignments; HRMS (LDI-FT-ICR) $m / z\left([\mathrm{M}]^{+}\right.$) calcd for $\mathrm{C}_{37} \mathrm{H}_{23} \mathrm{~F}_{5} \mathrm{O}_{3} \mathrm{~S} 642.12825$, found 642.12801 .

\section{Oligomer oP ${ }^{8} \mathrm{~F}_{3} \mathrm{OTf}$}

The general procedure was followed using $\mathbf{0} \mathbf{P}^{6} \mathbf{F}_{\mathbf{2}} \mathbf{O T f}(261 \mathrm{mg}, 0.40 \mathrm{mmol})$ and $\mathbf{B} 4$ (128 $\mathrm{mg}$, $0.60 \mathrm{mmol})$ at $70{ }^{\circ} \mathrm{C}$, giving $\mathbf{o P}^{\mathbf{8}} \mathbf{F}_{\mathbf{3}} \mathbf{O T f}$ as a white solid $(208 \mathrm{mg}, 63 \%)$ : m.p. $267.43{ }^{\circ} \mathrm{C}$ (dec.); See Table $\mathrm{S} 7$ for full ${ }^{1} \mathrm{H},{ }^{13} \mathrm{C}$, and ${ }^{19} \mathrm{~F}$ assignments; HRMS (LDI-FT-ICR) $m / z\left([\mathrm{M}]^{+}\right.$) calcd for $\mathrm{C}_{49} \mathrm{H}_{30} \mathrm{~F}_{6} \mathrm{O}_{3} \mathrm{~S}$ 812.18143, found 812.18083.

\section{Oligomer $\mathrm{oP}^{10} \mathrm{~F}_{4} \mathrm{OTf}$}

The general procedure was followed using $\mathbf{o P}^{\mathbf{8}} \mathbf{F}_{\mathbf{3}} \mathbf{O T f}(19 \mathrm{mg}, 0.023 \mathrm{mmol})$ and $\mathbf{B} 4(7 \mathrm{mg}$, $0.034 \mathrm{mmol})$ ) at $55{ }^{\circ} \mathrm{C}$, giving $\mathbf{o} \mathbf{P}^{10} \mathbf{F}_{4} \mathbf{O T f}$ as a white solid $(16 \mathrm{mg}, 69 \%)$; m.p. $301.80{ }^{\circ} \mathrm{C}$ (dec.); See Table $\mathrm{S} 8$ for full ${ }^{1} \mathrm{H},{ }^{13} \mathrm{C}$, and ${ }^{19} \mathrm{~F}$ assignments; HRMS (LDI-FT-ICR) $m / z\left([\mathrm{M}]^{+}\right.$) calcd for $\mathrm{C}_{61} \mathrm{H}_{37} \mathrm{~F}_{7} \mathrm{O}_{3} \mathrm{~S} 982.23461$, found 982.23389 . 


\section{Oligomer oP ${ }^{4} \mathrm{~F}_{4} \mathrm{OTf}$}

The general procedure was followed using 2-bromo-4,4'-difluoro-1,1'-biphenyl ${ }^{57}$ (30 mg, 0.11 mmol) and B3 (39 mg, $0.16 \mathrm{mmol})$ ) at $55^{\circ} \mathrm{C}$, giving $\mathbf{o P}{ }^{4} \mathbf{F}_{4} \mathbf{O T f}$ as a white solid (15.2 $\mathrm{mg}$, $26 \%$ ); m.p. $163.18{ }^{\circ} \mathrm{C}$ (dec.); ${ }^{1} \mathrm{H}$ NMR (400 MHz, $\left.\mathrm{CDCl}_{3}\right) \delta 7.28$ (dd, $\left.J=9.1,2.8 \mathrm{~Hz}, 1 \mathrm{H}\right)$, $7.24(\mathrm{~d}, J=9.3 \mathrm{~Hz}, 1 \mathrm{H}), 7.16(\mathrm{td}, J=8.2,2.7 \mathrm{~Hz}, 1 \mathrm{H}), 7.10(\mathrm{qd}, J=8.5,5.8 \mathrm{~Hz}, 3 \mathrm{H})$, 6.90-6.75 (m, 4H), $6.63(\mathrm{t}, J=6.6 \mathrm{~Hz}, 2 \mathrm{H}), 6.23-6.17(\mathrm{~m}, 1 \mathrm{H}) ;{ }^{13} \mathrm{C}\left\{{ }^{1} \mathrm{H}\right\}$ NMR $(126 \mathrm{MHz}$, $\left.\mathrm{CDCl}_{3}\right) \delta 161.82(\mathrm{~d}, J=248.4 \mathrm{~Hz}), 146.06,142.42,139.74,135.24(\mathrm{~d}, J=79.2 \mathrm{~Hz}), 133.14$ $(\mathrm{d}, J=30.7 \mathrm{~Hz}), 130.75(\mathrm{~d}, J=7.9 \mathrm{~Hz}), 130.01,118.70(\mathrm{~d}, J=22.4 \mathrm{~Hz}), 118.21(\mathrm{~d}, J=$ $22.1 \mathrm{~Hz}), 115.72-115.22(\mathrm{~m}), 114.87(\mathrm{~d}, J=21.3 \mathrm{~Hz}), 109.01(\mathrm{~d}, J=25.7 \mathrm{~Hz}) ;{ }^{19} \mathrm{~F}\left\{{ }^{1} \mathrm{H}\right\}$ $\operatorname{NMR}\left(376 \mathrm{MHz}, \mathrm{CDCl}_{3}\right) \delta-74.2,-110.1,-112.3,-115.1,-115.4$; HRMS (ESI-Orbitrap) $m / z\left([\mathrm{M}+\mathrm{H}]^{+}\right)$calcd for $\mathrm{C}_{25} \mathrm{H}_{14} \mathrm{~F}_{7} \mathrm{O}_{3} \mathrm{~S} 527.0552$, found 527.0546 .

\section{Oligomer $\mathrm{oP}^{6} \mathrm{~F}_{6}$}

A Schlenk vacuum tube was charged with $\mathbf{o P}^{5} \mathbf{F}_{5} \mathbf{O T f}(110 \mathrm{mg}, 0.18 \mathrm{mmol})$, 4-fluorophenylboronic acid (50 mg, $0.35 \mathrm{mmol}), \mathrm{Pd}(\mathrm{OAc})_{2}(4 \mathrm{mg}, 0.02 \mathrm{mmol})$, SPhos (9 mg, $0.02 \mathrm{mmol}$ ), and $\mathrm{K}_{3} \mathrm{PO}_{4}(113 \mathrm{mg}, 0.53 \mathrm{mmol})$, then evacuated and back-filled with argon $(3 \times)$. Dry THF (4 $\mathrm{mL})$ and $\mathrm{H}_{2} \mathrm{O}(1 \mathrm{~mL})$ were added under a positive pressure of argon. The reaction mixture was degassed by three freeze-pump-thaw cycles. The Schlenk tube was sealed and heated at $80{ }^{\circ} \mathrm{C}$ for $24 \mathrm{~h}$, then cooled and diluted with EtOAc $(10 \mathrm{~mL})$ and $\mathrm{H}_{2} \mathrm{O}(10 \mathrm{~mL})$. The aqueous layer was extracted with EtOAc $(3 \times 20 \mathrm{~mL})$ and the combined organic layers washed with brine $(20 \mathrm{~mL})$, then dried over $\mathrm{MgSO}_{4}$, filtered, and concentrated. Purification by flash chromatography ( $n$-hexane) followed by gel permeation chromatography gave $\mathbf{o P}^{\mathbf{6}} \mathbf{F}_{\mathbf{6}}$ as a white solid (8 mg, 8\%): m.p. $217.90{ }^{\circ} \mathrm{C}$ (dec.); see Tables $\mathrm{S} 3$ and $\mathrm{S} 4$ for full ${ }^{1} \mathrm{H},{ }^{13} \mathrm{C}$, and ${ }^{19} \mathrm{~F}$ assignments of major and minor conformers; HRMS (LDI-FT-ICR) $m / z\left([\mathrm{M}]^{+}\right)$calcd for $\mathrm{C}_{36} \mathrm{H}_{20} \mathrm{~F}_{6} 566.14637$, found 566.14631. 


\section{Oligomer $\mathrm{oP}^{6} \mathrm{~F}_{3}$}

A Schlenk vacuum tube was charged with $\mathbf{o P}^{\mathbf{5}} \mathbf{F}_{\mathbf{3}} \mathbf{O T f}$ (30 $\mathrm{mg}, 0.05 \mathrm{mmol}$ ), phenylboronic acid (13 mg, $0.1 \mathrm{mmol}), \mathrm{Pd}(\mathrm{OAc})_{2}$ (2 mg, $\left.0.009 \mathrm{mmol}\right)$, SPhos (3 mg, $0.007 \mathrm{mmol}$ ), and $\mathrm{K}_{3} \mathrm{PO}_{4}(33 \mathrm{mg}, 0.15 \mathrm{mmol})$, then evacuated and back-filled with argon $(3 \times)$. Dry THF (4 $\mathrm{mL})$ and $\mathrm{H}_{2} \mathrm{O}(1 \mathrm{~mL})$ were added under a positive pressure of argon. The reaction mixture was degassed by three freeze-pump-thaw cycles. The Schlenk tube was sealed and heated at $80{ }^{\circ} \mathrm{C}$ for $24 \mathrm{~h}$, then cooled and diluted with EtOAc $(10 \mathrm{~mL})$ and $\mathrm{H}_{2} \mathrm{O}(10 \mathrm{~mL})$. The aqueous layer was extracted with EtOAc $(3 \times 20 \mathrm{~mL})$ and the combined organic layers washed with brine $(20 \mathrm{~mL})$, then dried over $\mathrm{MgSO}_{4}$, filtered, and concentrated. Purification by flash chromatography ( $n$-hexane) followed by gel permeation chromatography gave $\mathbf{o P}^{\mathbf{6}} \mathbf{F}_{\mathbf{3}}$ as a white solid (5.2 mg, 20\%): m.p. $232.10{ }^{\circ} \mathrm{C}$ (dec.); see Tables $\mathrm{S} 1$ and $\mathrm{S} 2$ for full ${ }^{1} \mathrm{H},{ }^{13} \mathrm{C}$, and

${ }^{19} \mathrm{~F}$ assignments of major and minor conformers; HRMS (LDI-FT-ICR) $m / z\left([\mathrm{M}]^{+}\right)$calcd for $\mathrm{C}_{36} \mathrm{H}_{23} \mathrm{~F}_{3}$ 512.17463, found 512.17497.

\section{Acknowledgements}

We thank the National Science Foundation (CHE-1904236) and the Volwiler Distinguished Research Professorship for support of this work. The $400 \mathrm{MHz}$ NMR spectrometer used in this work was purchased with the assistance of the National Science Foundation (CHE-1919850). The X-ray diffractometer housed at Miami University was purchased with the assistance of the National Science Foundation (CHE-1532402).

\section{References}

(1) Gellman, S. H. Foldamers: a manifesto. Acc. Chem. Res. 1998, 31, 173-180.

(2) Wang, P. S. P.; Schepartz, A. $\beta$-Peptide bundles: Design. Build. Analyze. Biosynthesize. Chem. Commun. 2016, 52, 7420-7432. 
(3) Hill, D. J.; Mio, M. J.; Prince, R. B.; Hughes, T. S.; Moore, J. S. A field guide to foldamers. Chem. Rev. 2001, 101, 3893-4011.

(4) Smaldone, R. A.; Moore, J. S. Foldamers as reactive sieves: Reactivity as a probe of conformational flexibility. J. Am. Chem. Soc. 2007, 129, 5444-5450.

(5) Srinivas, K.; Kauffmann, B.; Dolain, C.; Léger, J.-M.; Ghosez, L.; Huc, I. Remote substituent effects and regioselective enhancement of electrophilic substitutions in helical aromatic oligoamides. J. Am. Chem. Soc. 2008, 130, 13210-13211.

(6) Hu, H.-Y.; Xiang, J.-F.; Cao, J.; Chen, C.-F. Folding-induced selective hydrogenation of helical 9,10-anthraquinone analogues. Org. Lett. 2008, 10, 5035-5038.

(7) Kwon, S.; Kim, B. J.; Lim, H.-K.; Kang, K.; Yoo, S. H.; Gong, J.; Yoon, E.; Lee, J.; Choi, I. S.; Kim, H.; Lee, H.-S. Magnetotactic molecular architectures from self-assembly of $\beta$-peptide foldamers. Nat. Commun. 2015, 6, 8747.

(8) Yin, J.; Khalilov, A. N.; Muthupandi, P.; Ladd, R.; Birman, V. B. Phenazine-1,6dicarboxamides: Redox-responsive molecular switches. J. Am. Chem. Soc. 2019, 142, 60-63.

(9) Girvin, Z. C.; Gellman, S. H. Foldamer catalysis. J. Am. Chem. Soc. 2020, 142, $17211-17223$.

(10) Legrand, B.; Aguesseau-Kondrotas, J.; Simon, M.; Maillard, L. Catalytic foldamers: When the structure guides the function. Catalysts 2020, 10, 700.

(11) Rivera-Fuentes, P.; Alonso-Gómez, J. L.; Petrovic, A. G.; Santoro, F.; Harada, N.; Berova, N.; Diederich, F. Amplification of chirality in monodisperse, enantiopure alleno-acetylenic oligomers. Angew. Chem., Int. Ed. 2010, 49, 2247-2250.

(12) Yashima, E.; Ousaka, N.; Taura, D.; Shimomura, K.; Ikai, T.; Maeda, K. Supramolecular helical systems: Helical assemblies of small molecules, foldamers, and polymers with chiral amplification and their functions. Chem. Rev. 2016, 116, 13752-13990. 
(13) Ferrand, Y.; Kendhale, A. M.; Kauffmann, B.; Grélard, A.; Marie, C.; Blot, V.; Pipelier, M.; Dubreuil, D.; Huc, I. Diastereoselective encapsulation of tartaric acid by a helical aromatic oligoamide. J. Am. Chem. Soc. 2010, 132, 7858-7859.

(14) Mateus, P.; Jacquet, A.; Méndez-Ardoy, A.; Boulloy, A.; Kauffmann, B.; Pecastaings, G.; Buffeteau, T.; Ferrand, Y.; Bassani, D. M.; Huc, I. Sensing a binding event through charge transport variations using an aromatic oligoamide capsule. Chem. Sci. 2021, 12, 3743-3750.

(15) Hou, J.; Shao, X.; Chen, G.; Zhou, Y.; Jiang, X.; Li, Z. Hydrogen bonded oligohydrazide foldamers and their recognition for saccharides. J. Am. Chem. Soc. 2004, 126, 1238612394.

(16) Juwarker, H.; Suk, J.-m.; Jeong, K.-S. Foldamers with helical cavities for binding complementary guests. Chem. Soc. Rev. 2009, 38, 3316-3325.

(17) Wittig, G.; Lehmann, G. Über die reaktionsweise von 2.2'-dilithium-diphenyl gegenüber metallchloriden; gleichzeitig ein beitrag zur synthese von poly-o-phenylenen. Chem. Ber. 1957, 90, 875-892.

(18) Blake, A. J.; Cooke, P. A.; Doyle, K. J.; Gair, S.; Simpkins, N. S. Poly-orthophenylenes: synthesis by Suzuki coupling and solid state helical structures. Tetrahedron Lett. 1998, 39, 9093-9096.

(19) He, J.; Crase, J. L.; Wadumethrige, S. H.; Thakur, K.; Dai, L.; Zou, S.; Rathore, R.; Hartley, C. S. ortho-Phenylenes: unusual conjugated oligomers with a surprisingly long effective conjugation length. J. Am. Chem. Soc. 2010, 132, 13848-13857.

(20) Ohta, E.; Sato, H.; Ando, S.; Kosaka, A.; Fukushima, T.; Hashizume, D.; Yamasaki, M.; Hasegawa, K.; Muraoka, A.; Ushiyama, H.; Yamashita, K.; Aida, T. Redox-responsive molecular helices with highly condensed $\pi$-clouds. Nat. Chem. 2011, 3, 68-73. 
(21) Ando, S.; Ohta, E.; Kosaka, A.; Hashizume, D.; Koshino, H.; Fukushima, T.; Aida, T. Remarkable effects of terminal groups and solvents on helical folding of $o$-phenylene oligomers. J. Am. Chem. Soc. 2012, 134, 11084-11087.

(22) Hartley, C. S. Folding of ortho-phenylenes. Acc. Chem. Res. 2016, 49, 646-654.

(23) Mathew, S. M.; Engle, J. T.; Ziegler, C. J.; Hartley, C. S. The role of arene-arene interactions in the folding of ortho-phenylenes. J. Am. Chem. Soc. 2013, 135, 67146722 .

(24) Perrin, C. L.; Dwyer, T. J. Application of two-dimensional NMR to kinetics of chemical exchange. Chem. Rev. 1990, 90, 935-967.

(25) Kinney, Z. J.; Hartley, C. S. Twisted macrocycles with folded ortho-phenylene subunits. J. Am. Chem. Soc. 2017, 139, 4821-4827.

(26) Kinney, Z. J.; Kirinda, V. C.; Hartley, C. S. Macrocycles of higher ortho-phenylenes: assembly and folding. Chem. Sci. 2019, 10, 9057-9068.

(27) Kirinda, V. C.; Schrage, B. R.; Ziegler, C. J.; Hartley, C. S. ortho-Phenylene-based macrocyclic hydrocarbons assembled using olefin metathesis. Eur. J. Org. Chem. 2020, $5620-5625$.

(28) Vemuri, G. N.; Pandian, R. R.; Spinello, B. J.; Stopler, E. B.; Kinney, Z. J.; Hartley, C. S. Twist sense control in terminally functionalized ortho-phenylenes. Chem. Sci. 2018, 9, 8260-8270.

(29) Didenko, T.; Liu, J. J.; Horst, R.; Stevens, R. C.; Wüthrich, K. Fluorine-19 NMR of integral membrane proteins illustrated with studies of GPCRs. Curr. Opin. Struct. Biol. 2013, 23, 740-747.

(30) Cobb, S. L.; Murphy, C. D. ${ }^{19}$ F NMR applications in chemical biology. J. Fluorine Chem. 2009, 130, 132-143. 
(31) Kitevski-LeBlanc, J. L.; Prosser, R. S. Current applications of ${ }^{19} \mathrm{~F}$ NMR to studies of protein structure and dynamics. Prog. Nucl. Mag. Res. Spectrosc. 2012, 62, 1-33.

(32) Bucci, R.; Contini, A.; Clerici, F.; Beccalli, E. M.; Formaggio, F.; Maffucci, I.; Pellegrino, S.; Gelmi, M. L. Fluoro-aryl substituted $\alpha, \beta^{2,3}$-peptides in the development of foldameric antiparallel $\beta$-sheets: A conformational study. Front. Chem. (Lausanne, Switz.) 2019, \%, 192.

(33) Hassoun, A.; Grison, C. M.; Guillot, R.; Boddaert, T.; Aitken, D. J. Conformational preferences in the $\beta$-peptide oligomers of cis-2-amino-1-fluorocyclobutane-1-carboxylic acid. New J. Chem. 2015, 39, 3270-3279.

(34) Cho, J.; Sawaki, K.; Hanashima, S.; Yamaguchi, Y.; Shiro, M.; Saigo, K.; Ishida, Y. Stabilization of $\beta$-peptide helices by direct attachment of trifluoromethyl groups to peptide backbones. Chem. Commun. 2014, 50, 9855-9858.

(35) Gimenez, D.; Aguilar, J. A.; Bromley, E. H. C.; Cobb, S. L. Stabilising peptoid helices using non-chiral fluoroalkyl monomers. Angew. Chem., Int. Ed. 2018, 57, 10549-10553.

(36) Gan, Q.; Bao, C.; Kauffmann, B.; Grélard, A.; Xiang, J.; Liu, S.; Huc, I.; Jiang, H. Quadruple and double helices of 8-fluoroquinoline oligoamides. Angew. Chem., Int. Ed. 2008, 47, 1715-1718.

(37) Wu, C.-F.; Li, Z.-M.; Xu, X.-N.; Zhao, Z.-X.; Zhao, X.; Wang, R.-X.; Li, Z.-T. Foldinginduced folding: the assembly of aromatic amide and 1,2,3-triazole hybrid helices. Chem.-Eur. J. 2014, 20, 1418-1426.

(38) Arenas, J. L.; Xu, Y.; Milcent, T.; Heijenoort, C. V.; Giraud, F.; Ha-Duong, T.; Crousse, B.; Ongeri, S. Fluorinated triazole foldamers: Folded or extended conformational preferences. ChemPlusChem 2021, 86, 241-251.

(39) Zornik, D.; Meudtner, R. M.; El Malah, T.; Thiele, C. M.; Hecht, S. Designing structural motifs for clickamers: Exploiting the 1,2,3-triazole moiety to generate conformationally restricted molecular architectures. Chem.-Eur. J. 2011, 17, 1473-1484. 
(40) Mathew, S.; Crandall, L. A.; Ziegler, C. J.; Hartley, C. S. Enhanced helical folding of ortho-phenylenes through the control of aromatic stacking interactions. J. Am. Chem. Soc. 2014, 136, 16666-16675.

(41) Ishikawa, S; Manabe, K Repetitive two-step method for oligoarene synthesis through rapid cross-coupling of hydroxyphenylboronic acids and anhydrides. Chem. Lett. 2006, 35, 164-165.

(42) Zhou, Q. J.; Worm, K.; Dolle, R. E. 10-Hydroxy-10,9-boroxarophenanthrenes: versatile synthetic intermediates to 3,4-benzocoumarins and triaryls. J. Org. Chem. 2004, 69, $5147-5149$.

(43) Albéniz, A. C.; Casares, J. A. Palladium-mediated organofluorine chemistry. Adv. Organomet. Chem. 2014, 62, 1-110.

(44) Sharif, M.; Maalik, A.; Reimann, S.; Feist, H.; Iqbal, J.; Patonay, T.; Villinger, A.; Langer, P. Synthesis of functionalized fluorinated terphenyls by site-selective SuzukiMiyaura cross-coupling reactions of dibrominated fluorobenzenes. J. Fluorine Chem. 2013, 146, 19-36.

(45) Hartley, C. S.; He, J. Conformational analysis of o-phenylenes: helical oligomers with frayed ends. J. Org. Chem. 2010, 75, 8627-8636.

(46) Jain, R.; Bally, T.; Rablen, P. R. Calculating accurate proton chemical shifts of organic molecules with density functional methods and modest basis sets. J. Org. Chem. 2009, $74,4017-4023$.

(47) Marchione, A. A.; Dooley, R. J.; Conklin, B. Comparison of ${ }^{1} \mathrm{H}^{-19} \mathrm{~F}$ two-dimensional NMR scalar coupling correlation pulse sequences. Magn. Reson. Chem. 2014, 52, 183-189.

(48) Macheteau, J.-P.; Oulyadi, H.; van Hemelryck, B.; Bourdonneau, M.; Davoust, D. 2D experiments for the characterization of fluorinated polymers: pulsed-field gradients ${ }^{1} \mathrm{H}-{ }^{19} \mathrm{~F}$ hetero-COSY and its selective version. J. Fluorine Chem. 2000, 104, 149-154. 
(49) Smyslova, P.; Popa, I.; Lyčka, A.; Tejral, G.; Hlavac, J. Non-catalyzed click reactions of ADIBO derivatives with 5-methyluridine azides and conformational study of the resulting triazoles. PLoS One 2015, 10, e0144613.

(50) Saunders, C.; Khaled, M. B.; Weaver, J. D.; Tantillo, D. J. Prediction of ${ }^{19}$ F NMR chemical shifts for fluorinated aromatic compounds. J. Org. Chem. 2018, 83, 32203225.

(51) Kirinda, V. C.; Hartley, C. S. Folding-controlled assembly of ortho-phenylene-based macrocycles. Chem. Sci. 2021, 12, 6992-7002.

(52) Hartley, C. S. Excited-state behavior of ortho-phenylenes. J. Org. Chem. 2011, 76, 9188-9191.

(53) Liu, J.; Zhou, X.; Wang, C.; Fu, W.; Chu, W.; Sun, Z. Total synthesis of protosappanin $\mathrm{A}$ and its derivatives via palladium catalyzed ortho $\mathrm{C}-\mathrm{H}$ activation/C-C cyclization under microwave irradiation. Chem. Commun. 2016, 52, 5152-5155.

(54) Manabe, K.; Ishikawa, S. Ortho-selective cross-coupling of fluorobenzenes with Grignard reagents: Acceleration by electron-donating ortho-directing groups. Synthesis 2008, $2645-2649$.

(55) Jurrat, M.; Maggi, L.; Lewis, W.; Ball, L. T. Modular bismacycles for the selective C-H arylation of phenols and naphthols. Nat. Chem. 2020, 12, 260-269.

(56) Taeufer, T.; Pospech, J. Palladium-catalyzed synthesis of N,N-dimethylanilines via Buchwald-Hartwig amination of (hetero)aryl triflates. J. Org. Chem. 2020, 85, 70977111.

(57) Suzuki, N.; Fujita, T.; Ichikawa, J. Method for the synthesis of dibenzo $[g, p]$ chrysenes: Domino Friedel-Crafts-type cyclization of difluoroethenes bearing two biaryl groups. Org. Lett. 2015, 17, 4984-4987. 